\title{
Why Do Men Go Blind in the Theatre? Gender Riddles and the Fools' Play in the Italian Renaissance Comedy Gl'Ingannati (1532)
}

\author{
Katja Gvozdeva
}

Historians of theatre emphasise the importance of the visual for Renaissance theatre not only because of its obvious significance in staged performance but also due to 'the greater impact of visual rather than spoken material, arguing that the audience's perception of a play was determined more by what they saw than by what they heard'. ${ }^{1}$ One of the most powerful Renaissance stage devices used to attract and to challenge the visual perceptions of the audience was cross-dressing. This theatrical device made possible what contemporary critics call playful 'gender trouble' on the Renaissance stage. ${ }^{2}$ Italian, French, Spanish, and English (Shakespearian) comedy presented its audience not simply with men in women's clothing but rather a highly complex gender construct known as double cross-dressing: a male (boy) actor plays a female character who dresses up in men's apparel in order to herself play a male role within the context of the play. In other words, a male actor plays a female character playing a male character. Early modern European comedy's experimentation with gender fascinates us today, and cross-dressing in comedy has therefore been investigated by a wide range of influential theatre historians. These scholars, however, diverge in their critical accounts on one very central point: what did early modern audiences see in the cross-dressed actor/character and what was at stake - and being questioned - in this playful performance: masculinity, femininity, the category of gender, binary thinking? Can we even be sure that all spectators - male and female — saw the same thing when observing a male actor performing a female character dressed as a man? The human eye, to quote anthropologist David Gilmore, is both bipolar and bisexual, both masculine and feminine'. The male eye, in traditional Mediterranean

1 Domenico Pietropaolo, 'The Stage in the Text: A Theatrical Stratification of Italian Renaissance Comedy', in Comparative Critical Approaches to Renaissance Comedy, ed. by Donald Beecher and Massimo Ciavoletta (Ottawa: Dovehouse Editions Canada, 1986), p. 45.

2 Laura Giannetti, Lelia's Kiss: Imagining Gender, Sex, and Marriage in Italian Renaissance Comedy (Toronto: University of Toronto Press, 2009), p. 47. 
society, was conceived of as an instrument of 'ocular attack' - 'an organ of both predation and penetration'. In this sense, a woman who appeared in a public place — in our case, at the theatre — could be "had" by sight' if she established eye contact with a man. ${ }^{3}$ We should ask, therefore, whether the cross-dressed figure elicited the same kind of emotional and cognitive response from both male and female spectators.

Cross-dressing in comedy has its theatrical origins in Italy, and we can identify double cross-dressing in several plays from the first third of the sixteenth century. All of these were originally performed during Carnival and were based on learned and classical as well as on popular and vernacular sources. ${ }^{4}$ Gl'Ingannati (The Deceived), which was written and performed in Siena in $153^{2}$ by the Academy of the Intronati, if not the earliest, is certainly one of the most influential Italian Renaissance comedies. Critics recognise in it 'a sort of archetype for subsequent European theatre' because it 'takes the theatrical discourse on gender a step further. ${ }^{5}$ This passage from Laura Giannetti's important work on the Intronati's comedy follows a major current of recent interpretations by stressing that it is a site for the emancipation of gender discourse. Can these discursive interpretations, however, hold up to an analysis of the play's gender work that examines the visual strategies of Gl'Ingannati in the context of the carnivalesque rituals in which this Renaissance comedy was embedded?

The first public performance of Gl'Ingannati in 1532 was a carnivalesque event, yet the play's dynamics in general-and, especially, its gender dynamics - have been little examined from this perspective. This is due, in part, to misapprehensions (that are shared by nearly all scholarly work on the play to date) of the carnivalesque, which is associated with notions of the popular, the lower body, vulgarity, and roughness, leading scholars to identify and analyse its elements largely on the level of secondary characters, mostly servants. As a carnivalesque technique, therefore, cross-dressing has not been explored in its full semantic richness but has been reduced to the topos of 'the world turned upside down' ${ }^{6}$

3 David D. Gilmore, Carnival and Culture: Sex, Symbol and Status in Spain (New Haven: Yale University Press, 1998), p. 132.

4 See Giannetti, Lelia's Kiss, pp. 24-75; Louise George Clubb, Pollastra and the Origins of Twelfth Night: Parthenio, Commedia (1516) with an English Translation (Farnham: Ashgate Publishing Limited, 2010).

5 Giannetti, Lelia's Kiss, p. $5^{0 .}$

6 See, for example, Florindo Cerreta's critical introduction to La commedia degli Ingannati (Florence: Leo Olschki, 1980), p. 31; Nino Borsellino, Rozzi e Intronati. Esperienze e Forme Di Teatro Dal Decameron al Candelaio (Roma: Bulzoni, 1976), p. 76; the critical introduction of Marzia Pieri to Gl'Ingannati (Pisa: Titivillus, 2009), p. 23. On the carnivalesque roots of 
To more fully explore the role of the carnivalesque in Gl'Ingannati's performance of gender we must, I would argue, reverse the usual perspective (to borrow from Northrup Frye's methodological reflections in his notebooks and in 'The Argument of Comedy') by considering the ritual matrix of Gl'Ingannati not in terms of vestigial traces but rather in terms of its potentiality and teleology. ${ }^{7}$ This means setting aside the comedy's 'archaic' Roman comedy stratum, ${ }^{8}$ 'which is wholly recognised as an element of the past, to be observed, to be examined, or even on occasion to be consciously "revived"', in favour of focusing on the play's 'residual' stratum from late medieval ritual and the theatrical culture of the 'fools' play', 9 which was 'formed in the past, but is still active in the cultural process as an effective element of the present' 10

Three Views on Cross-Dressing in Comedy

To differentiate my approach to cross-dressing in comedy from contemporary scholarship on cross-dressing, I will begin with an overview of the existing interpretations of Gl'Ingannati and other plays derived from it (the crossdressing figure of Lelia, who appears in the first part of the comedy in men's clothing under the adopted name Fabio, is the prototype for the figure of Viola

cross-dressing in Renaissance comedy, see Maggie Günsberg, Gender and the Italian Stage: From the Renaissance to the Present Day (Cambridge: Cambridge University Press, 1997), pp. 51, 53 .

7 See Northrop Frye's Notebooks on Renaissance Literature, ed. by Michael Dolzani (Toronto: Victoria University Press, 2006), p. 101: 'Fundamentally what I want to do is to study ritual \& folklore origin of Shakespearean comedy with a reversal of the usual perspective, seeing the folklore not in terms of origins but in terms of teleology, not as vestigial sacrifice but as potential art'; ibid., p. 102: 'theory of drama, considering its social function \& its relation to religion and ritual, with a statement of my own plan to look at ritual teleologically instead of drama vestigially.' See also Northrop Frye, 'The Argument of Comedy', in English Institute Essays, ed. by Davis Allan Robertson (New York: Columbia University Press, 1949), pp. 58-73.

8 The question of the play's literary sources has been successfully solved by several generations of theatre historians. See Cerreta's critical introduction to La commedia degli Ingannati. Additions and precisions have been made by Louise George Clubb in her critical introduction to Pollastra.

9 I borrow this definition from the title of the seminal study dedicated to late medieval carnivalesque theatre. See Heather Arden, Fools' Plays: A Study of Satire in the Sottie (Cambridge: Cambridge University Press, 1980).

10 Raymond Williams, 'Dominant, Residual, and Emergent', in Marxism and Literature (Oxford: Oxford University Press, 1977, repr. 2009), p. 122. 
in Shakespeare's Twelfth Night, for example). These interpretations all focus on the doubly cross-dressed figure of Lelia/Fabio as the key to the comedy's action.

One large group of scholarly studies takes the idea of the dramatic character as the impetus for examining the comedy from the perspective of female gender construction. These studies approach the performance of cross-dressing as a theatrical technique that made visible what was invisible in the sixteenth century as a social reality, namely a young unmarried girl freely circulating in public spaces. Scenic female visibility is interpreted by these scholars in the feminist terms of liberation from patriarchal restriction, and Lelia is characterised as a positive example of feminine agency: 'enterprising, and even heroic, thus offering an alternative to the traditional passive and self-effacing ideal of female behaviour.' Consequently, the position of the play's male authors is understood to be philogynous and is discussed in relation to the academy's mission to open cultural activities to women. ${ }^{11}$

This approach contradicts the view of scholars like Melzi, who see in crossdressed Lelia a 'self-effacing woman'. This opposite interpretation is symptomatic of the contradictory nature of the figure herself, which has been explored by more recent scholars, for instance Laurie Shepard, who calls Lelia 'the most transgressive character in the comedy as well as the most virtuous'. Various attempts have been made to explain the contradictions inherent in this female character by pointing to Lelia's multiple cultural origins, ludic function, or hidden allegorical meaning. Though they have uncovered multiple facets of this enigmatic character, scholars have not yet succeeded in providing a fully satisfying solution to the play's central enigma. ${ }^{12}$

11 Giannetti, Lelia's Kiss, p. 28 and pp. 61-65. For similar interpretations see Cerreta's introduction in La commedia degli Ingannati, p. 25; Nerida Newbigin, 'Il Sacrificio e Gli Ingannati nel Carnevale senese del 1532', in Gl'Ingannati con il Sacrificio e la canzone nella morte d'una civetta, ed. by Nerida Newbigin (Bologna: Arnaldo Forni, 1984), p. xvii; Patrizia de Capitani, Du spectaculaire à l'intime: Un siècle de commedia erudita en Italie et en France (début XVI siècle-milieu du XVII siècle) (Paris: Honoré Champion, 2005), p. 89.

12 Robert C. Melzi, 'From Lelia to Viola', Renaissance Drama, 9 (1966), p. 70; Laurie Shepard, 'Siena 1531: Genesis of a European Heroine', Quaderno d'Italianistica, 26.1 (2005), p. 16. Richard Andrews, praising the innovation of the Intronati "who brought into "regular" comedy the figure of the faithful and yet enterprising heroine', explains the contradiction with folkloric origins. For him, Lelia/Fabio 'combines elements of the suffering heroine or "rejected bride" of folklore with the mischievous trickster of other types of tale'. See Richard Andrews, Scripts and Scenarios: The Performance of Comedy in Renaissance Italy (Cambridge: Cambridge University Press, 1993), pp. 90, 94; Richard Andrews, 'Gl'Ingannati as a Text for Performance', Italian Studies, 37 (1982), p. 40. Laura Giannetti interprets 
A second category of studies depart instead from the boy actor and understand cross- dressing as a theatrical means of constructing male gender. They reveal, in the interaction between actor and audience, rowdy masculine joking that is hardly compatible with Castiglione's prescriptions concerning male speech addressed to women. ${ }^{13}$ Central to this line of argumentation are not only heterosexual 'frictions' (Greenblatt), but also homosocial and homoerotic dynamics. Both Greenblatt and Günsberg, the most influential representatives of this approach, focus on the performative space created between the real presence of the male actor and the illusory presence of the female character on stage. Greenblatt considers the cross-dressed Shakespearean character, Viola (avatar of Lelia), against the background of Renaissance concepts of masculine individuation. Recognising, in cross-dressing rites, a crucial phase of the process of separation from the opposite sex that leads to the emergence of masculine identity, he interprets cross-dressed female characters as 'projected mirror images of masculine self-differentiation.. ${ }^{4}$

Günsberg, in contrast, examines cross-dressing from the collective perspective of male bonding, attributing to the female character the status of mask: 'For the male actor [...] his female masquerade thinly disguises his identity/ subjectivity as member of the dominant set of all-male relations governing patriarchal society, a position which is also occupied by the major addressee of the comedy, the male spectator.' As 'male fantasy object', the female character enables different forms of male bonding in the theatre, which Günsberg examines in terms of commodity fetishism, anthropological fetishism (trafic defemmes), and sexual fetishism. ${ }^{15}$

the play in terms of 'giochi of cross-dressing'. Her ludic reading serves the discovery of 'a more complex Lelia'. See Giannetti, 'On the Deceptions of the Deceived: Lelia and the Pleasures of Play', Modern Language Notes, 116.1 (2001), pp. 58, 70. Laurie Shepard argues in favour of political allegory, seeing, in Lelia, a representation of the city of Siena occupied by Spanish troops and, in her cross-dressed performance, a representation of nonconventional strategies by Sienese intellectuals that developed under difficult war conditions. See Shepard, 'Siena 1531', pp. 11, 17.

13 Marie-Francoise Piéjus, 'Les comédies des Intronati de Sienne: un theâtre pour les dames?', in La mujer: de los bastidores al proscenio en el teatro del siglo XVI, ed. by Irene Romera Pintor and Josep Lluís Sirena (Valencia: Universitat de València, 2011), pp. 251-64.

14 Stephen Greenblatt, 'Fiction and Friction', in Shakespearean Negotiations: The Circulation of Social Energy in Renaissance England (Berkeley: University of California Press, 1988), p. 92.

15 Günsberg, pp. 68, 72. In many ways, Günsberg's analysis of Italian drama follows the homosocial approach to desire in literary texts that was developed by Eve Kosofsky 
The deficiencies of both approaches are revealed by the cultural theory developed in Marjorie Garber's Vested Interests. Rather than looking through cross-dressing at gender categories, Garber proposes looking at the phenomenon of cross-dressing as 'the third'-not an instantiated, 'blurred' sex but a mode of articulation that questions binary thinking as such and introduces category crisis. ${ }^{16}$ We can find traces and repercussions of this critical intervention in recent interpretations of Gl'Ingannati that are characterised by multiple approaches to sex and gender and by some contradictions. For example, Gerry Milligan, who wrote of the 'ontological truth of the phallus' in the Intronati's play, also asserted that, 'in a brilliant exchange of scenes, Gl'Ingannati anticipates the gender criticism of the twentieth century, where there is an inability to locate gender beyond the putative understanding of discursive reinscription and repetition. ${ }^{17}$ For Milligan, the cross-dressing device is a 'meta-performative tool' that 'exposes the theatricality of gender performance in general' and 'threatens the notion of sexual category' ${ }^{18}$

These kinds of highly generalising conclusions - that praise early modern dramatic authors as the intellectual predecessors of Michel Foucault, Judith Butler, or Marjorie Garber-run the risk of anachronism. Preoccupied with questions that might arise for an audience from the ambiguous performance of a cross-dressed actor or character-questions that open up a space of multiple sexual and social possibilities - recent studies show little interest in the clear answer provided by the comedy to its male and female spectators via its powerful concluding image of marriage. This image celebrates a non-ambiguous conjunction of two polarised gender categories that are conceived in traditional patriarchal terms as 'natural' and as associated with licit sexuality. ${ }^{19}$

In my attempt to historicise the performance of cross-dressing in Renaissance comedy, I will argue that it is articulated, instead, as a question

Sedgwick. See her Between Men:English Literature and Male Homosocial Desire (New York: Columbia University Press, 1985).

16 See Marjorie B. Garber, Vested Interests: Cross-dressing and Cultural Anxiety (New York: Routledge, 1992), p. 85 .

17 Gerry Milligan, 'Behaving Like a Man: Performed Masculinities in Gl'Ingannati', Forum Italicum, 41.1 (2007), pp. 31, 32.

18 Ibid., pp. 29, 30, 33 .

19 On marriage as a 'measure for sex in the Renaissance: it disciplined, organized, and ultimately sanctioned sex', see Guido Ruggiero, Machiavelli in Love: Sex, Self, and Society in the Italian Renaissance (Baltimore: John Hopkins University Press, 2006), p. 226, n. 16; Guido Ruggiero, 'Marriage, Love, Sex, and Renaissance Civic Morality', in Sexuality and Gender in Early Modern Europe: Institutions, Texts, Images, ed. by James Grantham Turner (Cambridge: Cambridge University Press, 1993), pp. 10-30. 
that already contains within it a predetermined answer. In other words, I will interpret the performance of cross-dressing in the comedy as a carnivalesque visual and verbal riddling event ${ }^{20}$ that takes place on two levels of interaction: between the dramatic characters on stage and between the actors and their audience. This approach will bring us new insights into the play's dramatic structure, its illocutionary power, and its perlocutionary effect in performance.

Since our anonymous comedy was not only written collaboratively by academy members but also staged as their collective performance, the starting point of my interrogation is a question about the corporate identity of Intronati members in its relationship with carnivalesque culture in general and festive riddling in particular. What kind of group expresses itself through the dramatic medium of the comedy?

The first and most evident answer is, of course, one of the earliest (if not the first) formal Renaissance accademie, which were free associations of litterati that arose from loose humanist sodalitates but took a highly organised form: choosing a specific corporate name, inventing an emblem, adopting statutes, and elaborating a clear program of activities. Founded in 1525, the Academia degli Intronati saw as its cultural mission the revival of ancient cultural tradition in order to adapt it to early modern linguistic, aesthetic, and social conditions, requirements, and aspirations. Thus playwriting came to occupy an important place among academy activities as a means of reviving Roman comedy in new forms, while performing the academy's plays served to disseminate its cultural heritage among large, non-specialist audiences. Choosing to call themselves gli Intronati (which we might translate as the 'Deaf', 'Daft', 'Dazed', or 'Stunned'), members of the academy sought to proclaim their separation from 'the world' ('il mondo'), stressing their non-participation in the political life of the city in favor of humanistic concentration on literary studies-in other words, abandoning the vita attiva for the vita contemplativa. ${ }^{21}$

20 'A question which contains the answer' is the classic definition of the riddle given by Elli Köngäs Maranda in her seminal article 'The Logic of Riddles', in Structural Analysis of Oral Tradition, ed. by Pierre Maranda and Elli Köngäs-Maranda (Philadelphia: University of Pennsylvania Press, 1971), pp. 189-232 (p. 192).

21 For the history of this institution, see Lolita Petracchi Costantini, L'Accademia degli Intronati di Sienna e una sua commedia (Siena: La Diana, 1928); 'Accademia degli Intronati', in Michele Maylender, Storia delle Accademie d'Italia (Bologna: Cappelli, 1926-1930), III, 


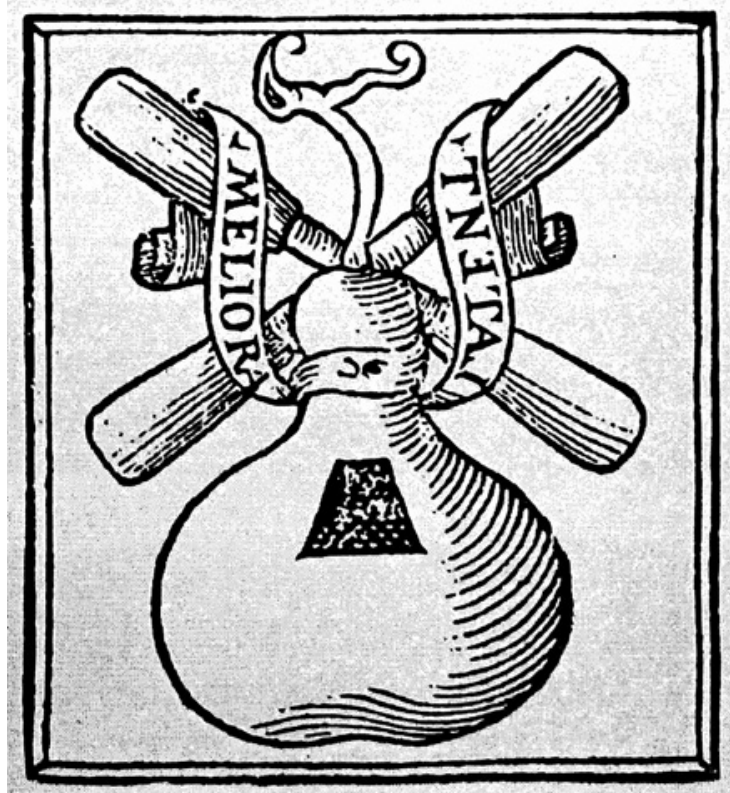

FIGURE 1 Emblem of the Accademia degli Intronati. Frontispiece. First edition of Gl'Ingannati (1537). https://archive.org/stream/ glingannaticoniloonewb\#page/n23/mode/2up.

It is also possible to give a second, parallel answer that is less obvious and that deserves a more detailed explanation. Opting for the whimsical collective name 'Intronati', which is also a synonym for 'Fools', the six young men who founded the academy consciously united as a carnivalesque society. ${ }^{22}$

On the Intronati emblem, folly is symbolised by a pumpkin-a carnivalesque metaphor for an empty head. The ribbon wearing the academic motto Meliora latent (the best is concealed) is playfully twisted, becoming a sign for

pp. 350-62; Laura Riccò, La 'miniera' accademica: Pedagogia, editoria, palcoscenico nella Siena del Cinquecento (Roma: Bulzoni, 2002). The Intronati have long been praised as the first European academy; strictly speaking, they represent one of the earliest institutionalised associations of litterati. See Léo Kosuta, 'L'académie siennoise: Une académie oubliée du XVI ${ }^{\mathrm{e}}$ siècle', Bullettino senese di storia patria, 87 (1980), pp. 123-57.

22 The carnivalesque aspects of the academy that are presented briefly here are more fully developed in my article 'Le monde ludique des académies italiennes: l'exemple des Intronati de Sienne', in Savoirs ludiques: Pratiques de divertissement et institutions savantes, littéraires et politiques dans l'Europe moderne, ed. by Katja Gvozdeva and Alexandre Stroev (Paris: Champion, 2013), pp. 49-88. 
carnivalesque inversion. The academy, by presenting itself in its programmatic texts as a society 'of Intronati, that is of stupid and foolish [men]' ('Intronatorum, hoc est stupidorum et fatuorum'), revives Socratic ignorance as a new humanist ideal. ${ }^{23}$ More importantly for our purposes, however, is that this emphasis on folly emerges from and participates in the late medieval European tradition of fools' societies, which are documented from the twelfth century onwards and were particularly active during the first half of the sixteenth century in various social milieu. ${ }^{24}$ Known in Italy under a variety of burlesque names that epitomised folly (Pazzi, Matti, Stolti, Asini), fools' societies had the duty and privilege of organising public festivities and of staging carnivalesque plays. Early academic sources list the Intronati as proud organisers of many different festive events: carnivalesque processions, royal entries, weddings, parlour games, and the staging of erudite comedies. ${ }^{25}$ All of these belong within the wide range of public performances that were intended, in Richard Trexler's words, 'to upgrad[e] carnival.' ${ }^{26}$

Of particular significance for the construction of a sixteenth-century academic collective identity was its affirmation that carnivalesque folly, combined with serious intellectual pursuits, constituted an ideal of masculine identity. According to one of its most important institutional texts, therefore, the Intronati claimed their just entitlement to the term 'Huomini', employing semantically significant capitalisation in order to name themselves 'Men at every hour of the day' ('Huomini da tutte quante l'ore'), whether in study or in recreation. ${ }^{27}$

23 See the letter by Mino Celsi in In haereticis coercendis quatenus progredi liceat; Poems; Correspondence, ed. by Peter G. Bietenholz (Naples: Prismi; Chicago: Newberry Library, 1982), p. 540. The Latin text has its origins in an Italian letter written by Celsi in May 1570, which is quoted in Leo Kosuta, 'Notes et documents sur Antonio Vignali (1500-1559)', Bullettino senese di storia patria, 89 (1982), p. 132.

24 Natalie Zemon Davis, 'The Reasons of Misrule: Youth Groups and Charivaris in SixteenthCentury France', Past and Present, 50 (Feb. 1971), pp. 43, 50.

25 See Scipione Bargagli, Delle lodi dell'academie: Oratione di Scipion Bargagli da lui recitata nell'Academia degi Accesi in Siena (Fiorenza: Bonetti, 1569), p. 32.

26 See Richard Trexler, 'The New Ritual Groups', in Public Life in Renaissance Florence (Ithaca: Cornell University Press, 1980), p. 414.

27 'A trattenimento, a festa, a veglia, a sollazzo intervenissono Accademici intronati: a' quali potevasi senz'alcun fallo, il nome attribuire d'Huomini (come dir si costumava) da tutte quante l'ore' ('the members of the Academy of the Intronati- to whom one could, without error, give the name of Men (as one used to say) at every hour of the day-attended entertainments, feasts, gatherings, amusements'). [Scipione Bargagli], Oratione in Lode 
By celebrating their academic anniversary on the first of May as 'the "re-greening" of the Dazed Pumpkin' ('rinverdimento della Zucca Intronata'), 28 the Intronati inscribed the birth of their company into the so-called 'green world' of traditional May festivities, which was the domain of youth. And indeed, historical anthropology recognises fools' societies as organised youth groups (societates adulescentium et juvenum) that were restricted to young men. ${ }^{29}$ According to Taddei, the names of these joyous companies make sense given the premodern perception of youth as an age of deranged senses, in opposition to the wisdom of maturity. ${ }^{30}$ If we add to this interpretation the

dell'Accademia degli 'ntronati dello Schieto Intronato (1603), in Delle commedie degl'Accademici Intronati, (Siena: Florimi, 1611), II, p. 519.

28 Girolamo Bargagli, Dialogo de' giuochi che nelle vegghie sanesi si usano di fare (1572), ed. by Patrizia D'Incalci Ermini, introd. by Ricardo Bruscagli (Siena: Accademia Senese degli Intronati, 1982), p. 50.

29 There is currently no comprehensive cultural study of European fools' societies. The work of Giuseppe Cesare Pola Falletti di Villafalletto can be consulted, but it does not hold to contemporary scholarly standards. See Giuseppe Cesare Pola Falletti di Villafalletto, Le gaie compagnie dei giovani del vecchio Piemonte (Casale: Maglietta, 1937; repr. Torino: Omega, 1994); Associazioni giovanili e feste antiche, 2 vols (Milano: Fratelli Bocca, 1939). Besides the seminal article of Zemon Davis quoted above, I employ as sources on this topic a selection of works dedicated to different national contexts and social milieux: AnneMarie Lecoq, 'La città festeggiante: Les Fêtes publiques au XVe et XVI siècles', Revue de l'Art, 33 (1976), p. 95; Illaria Taddei, Fanciulli e Giovani: Crescere a Firenze nel Rinascimento (Firenze: Olschki, 2001), pp. 100-03; Illaria Taddei, 'Une sociabilité bien ordonnée: Les societates puerorum, adulescentium et juvenum à Florence au XVe siècle', in Les lieux de sociabilité religieuse à la fin du Moyen Âge, Actes des journées d'étude (19-20 avril 2002), Université de Grenoble 2, ed. by Pierrette Paravy and Illaria Taddei (Grenoble: CRHIPACESAM, 2006), pp. 23-35; Alessandro Barbero, 'La violenza organizzata: L'Abbazia degli Stolti a Torino fra Quattro e Cinquecento', Bolletino storico subalpino, 88 (1990); Piercarlo Grimaldi, 'Il corpo e la festa: Strategie sessuali contadine', in Il corpo e la festa: Universi simbolici e prattiche della sessualità popolare, ed. by Piercarlo Grimaldi (Roma: Meltemi, 1999), p. 18; Konrad Eisenbichler, The Boys of the Archangel Raphael: A Youth Confraternity in Florence 1411-1785 (Toronto: University of Toronto Press, 1998); Martine Grinberg, 'Carnaval et société urbaine, $\mathrm{XIV}^{\mathrm{e}}-\mathrm{XVI} \mathrm{e}^{\mathrm{e}}$ siècles: le royaume dans la ville', Ethnologie française, 4 (1974), pp. 215-44; Jacques Rossiaud, 'Fraternités de jeunesse et niveaux de culture dans les villes du Sud-Est à la fin du Moyen Âge', Cahiers d'histoire, 21 (1976), pp. 67-102; Emmanuel Le Roy Ladurie, Le Carnaval de Romans: De la Chandeleur au mercredi des Cendres 1579-1580 (Paris: Gallimard, 1979); Robert Muchembled, 'Les jeunes, les jeux et la jeunesse en Artois au XVI ${ }^{\mathrm{e}}$ siècle', in Les jeux à la Renaissance, Actes du XXII ${ }^{\mathrm{e}}$ colloque international d'études humanistes, Tours, Juillet 1980, ed. by Philippe Aries and JeanClaude Margolin (Paris: Vrin, 1982), pp. 563-79. 
notion that male youth formed a 'liminal group' in early modern Italian urban communities - excluded from government and public affairs for their lack of dispassionate reason but sanctioned as specific 'ritual groups' responsible for festive performances ${ }^{31}$ —names of youth societies emblematising folly acquire the dynamic sense of the ritual transformation from silly boy to wise man. The social mission of societates adulescentium et juvenum - to lead their foolish adolescent members through festive rites to the age of reason-coincides with the pedagogical goal of the Intronati, which considered itself a school for 'Men'. The academy saw itself as distinct from institutions that were ruled by their fathers' generation - in particular from the Sienese Studio (University) because the Intronati catered to the 'natural instinct' ('naturale istinto') of young boys who sought pleasure and enjoyment, offering them the ludic and festive framework of 'pleasant studies' ('piacevoli studi'). ${ }^{32}$ The dynamic relationship between the opposites of study and entertainment, folly and wisdom, youth and maturity that characterised the academy's collective identity must be kept in mind when considering the fourth dynamic opposition, masculine and feminine, that is inscribed in the institutional matrix of the Intronati.

The goal of forming men out of boys placed members of youth society in opposition to women, such that the institution appeared oriented towards the affirmation of masculine power through male bonding. Founded as a society for humanistic intellectual pursuits by students of the Sienese Studio, the academy — at least in its initial phase under consideration here-was closed to women, who did not have access to a university education and its Latin curriculum. The Latin motto of the academy, Meliora latent, which figures on its emblem, circumscribes an intensely masculine community. The body of the emblem symbolises this community not only through the Silenic image

$31 \quad$ Trexler, pp. $387-400$.

32 'Perciò che ponendosi il più delle volte i giovinetti ad una sorte di studio per istimolo e per ordine de'padri, i quali non mettendo cura a quel che li figliuoli sieno atti o inclinati ad essere $[. .$.$] avviene che gli hanno talora indirizzati a cosa molto dal loro naturale istinto$ contraria. [...] E però sono in età da potere di loro stessi deliberare, là s'indirizzano dove si sentono dalla loro propria inclinazione tirare. E così seguendo la lor vocazione, singolari e famosi uomini son divenuti' ('Since young men most often undertake a particular kind of study with the impetus and under the orders of their fathers, who care not at all about whatever their sons are suited or inclined to be [...] it happens that [fathers] direct [their sons] towards something that is very much contrary to their natural instincts. [...] And yet [young men] are old enough to themselves determine the direction in which they feel pulled by their own inclinations. And, following their vocation in this way, they have become outstanding and famous men'). Bargagli, Dialogo de' Giuochi, pp. 134, 135-36. All translations are mine unless otherwise noted. 
of the pumpkin, foolish in its appearance but containing the salt of knowledge, but also through the image of crossed phallic pestles, masculine ingegni (wits) triturating ancient wisdom. ${ }^{33}$ In their homosocial journey towards everincreasing knowledge, members of the academy could emphasise their own and other community members' masculinity in many ways, including producing misogynous discourse and homoerotic fantasies, as well as staging themselves as a homosexual network, as is the case in the famous playful academic dialogue La Cazzaria. ${ }^{34}$

While highlighting piacevoli studi conforms to the 'natural instincts' of young boys, the programmatic texts of the Intronati imply not only the homosocial pleasure of the acquisition of knowledge in the familiar atmosphere of male friendship and love that reigned behind the closed doors of the academythat is, in the depths of the zucca intronata-but also the heterosocial pleasure of the dissemination of acquired knowledge in playful forms adopted for large non-specialised audiences that are represented by the noblewomen whom the Intronati met in public spaces of carnivalesque entertainment. Literary parlour games and comedies by academicians were thus expressly dedicated to noblewomen, a phenomenon that displays the philogynous facet of the Intronati.

These two apparently contradictory aspects of the society-misogynous and philogynous - are not only problematic for us today. They were equally so for the contemporaries of the Intronati, based upon what we can deduct from the repeated attempts of their representatives to defend this new conception of the cultural institution of the accademia from severe criticism - a defence that was carried out in several institutional texts by the Intronati. First among these are the apologetic fragments of the Dialogo de' Giuochi, where Girolamo Bargagli (1537-1586), praising the Intronati as a school of men, also insists on

33 The intriguing emblem of the Intronati was the object of numerous interpretations during the sixteenth century. The most informative of these is the dialogic exegesis in an academic treatise first published in 1594. See Scipione Bargagli, Dell'imprese (Venetia: Francesco de' Franceschi, 1621), pp. 520-25.

34 See Antonio Vignali, La Cazzaria: The Book of the Prick, ed. and trans. by Ian Frederick Moulton (New York: Routledge, 2003), and the editor's insightful introduction. I will leave aside the question of whether this playful text refers to the actual homosexual practices of academy members or is a product of pure imagination, following Gregory Bateson's reflection on the subject in terms of his theory of play framing: 'pseudohomosexuality of the fantasy does not stand for any real homosexuality or feeds its etiological roots. The symbols do not denote homosexuality, but do denote ideas for which homosexuality is an appropriate symbol'. See his 'Theory of Play and Fantasy', in The Game Design Reader: A Rules of Play Anthology, ed. by Katie Salen and Eric Zimmerman (Cambridge: Miт Press, 2006), p. 320. 
their explicit intention to please noblewomen. ${ }^{35}$ In such texts, the academic institution, symbolised by the pumpkin, appears as a dynamic relationship between its misogynous inside and philogynous outside - between the acquisition of knowledge, which concerns only men, and its dissemination, which is addressed to women. The notion of pleasure here has a clear erotic and heterosexual connotation: it is in connection with these female 'recipients' that the pumpkin on the academy's emblem reveals its second meaning as a carnivalesque symbol of the female lower body, and that the emblem's phallic pestles, representing the academic idea of knowledge dissemination, acquire a playful association with insemination.

This emblem thus appears as a pictorial riddle with two different solutions, corresponding in its basic semiotic structure to the definition of the verbal riddle-il giuoco degl'Indovinelli - which was supplied by the Intronati in the treatise on parlour games, Il Dialogo de' Giuochi ${ }^{36}$ According to the treatise's author, a riddle should show at first glance something indecent or obscene ('qualcosa poco onesto') in order to increase the viewer's pleasure of discovering in it a decent thing ('convenevol cosa') that is very different in sense from the riddle's initial appearance. Il Dialogo thus presents a description of the ludic genre of erotic riddles that was widespread as a social custom in Italy during the sixteenth century (before the beginning of the Counter-Reformation campaign against carnivalesque abuses) not only in popular settings but also within the framework of aristocratic and academic carnivalesque gatherings. But our Sienese author does not give any examples of the riddling game in his treatise. The only sources that can inform us today about various aspects of the game's process ('il processo del giuoco', in Bargagli's words) are literary representations of aristocratic and academic riddling sessions.

Let us therefore very briefly consider, from the trifold perspective of social norms, gendered interactions, and academic culture, the famous collection Piacevoli Notti (1550-1553), which was composed by the Venetian author Straparola and is from the same period that Bargagli evokes in his Dialogo de' Giuochi. The Notti include numerous depictions of riddling sessions arranged among Venetian litterati and young noblewomen, all of which follow the same rule: the riddle with a double solution, by suggesting something obscene, performs a playful transgression of social convention and engenders laughter

\footnotetext{
35 'Né biasimino gli Accademici, perché abbiano oggetto di piacere a pregiate donne' ('The Academics should not be blamed, because their purpose is to please precious women'). Bargagli, Dialogo de' giuochi, pp. $135^{-36}$.

$3^{6} \quad$ Ibid., p. 62.
} 
among the players that exposes, then dissipates, erotic energies. The suggested but never verbalised obscene solution is immediately chased from the aristocratic community of players when another, entirely decent, solution is found. Declaring this decent solution not only serves to demonstrate the intellectual capacities of the players but is simultaneously a performative act that reestablishes social order as well as behavioral norms. What is described by the riddler in a way that suggests a penis, for example, might reveal itself in the solution to be a pen, the instrument used to create concetti. ${ }^{37}$ This playful connection between the masculine body and masculine wit is particularly relevant for an academic culture centred on the construction of learned masculinity.

The academic play with masculine and feminine sexual symbols that was transposed into the Intronati emblem in the form of an erotic riddle not only refers to the concept of procreative masculinity that developed in early modern learned discourse on medicine and law. ${ }^{38}$ Its roots are also to be found in traditional fertility rituals that were engaged in by male Sienese youth during Carnival. Reflecting on the ritual origins of carnivalesque entertainments conceived by the Intronati for noblewomen, Bargagli refers to the following custom: young boys run through the city armed with phallic ladles, using them to strike women who want to get pregnant. Here the role of young foolish males is dominant and aggressive, and the role of young women is passive and receptive. ${ }^{39}$ This carnivalesque ritual is helpful in interpreting the composition of an academic emblem that shows us not only the relationship between the inside and outside of a pumpkin but also the hierarchical construction of a pumpkin surmounted by pestles. As a pictorial transposition of the collective purposes of the Intronati, their emblem-conceived in the form of a riddle with a double solution - unites two different levels of the academic body, representing the community as a collective masculine head oscillating between apparent folly and hidden wisdom, and rendering its relationship with women

37 For more extensive consideration of this literary example in relation to the social functions of riddling and for the historical evolution of the riddle as a literary genre, see my 'Spielprozess und Zivilisationsprozess: Emotionales Rätsel in Italien und Frankreich zwischen 1475 und 1638', in Scham und Schamlosigkeit. Grenzverletzungen in Literatur und Kultur der Vormoderne, ed. by Katja Gvozdeva and Hans Rudolf Velten (Berlin: De Gruyter, 2011), pp. 363-95.

38 For procreative masculinity in the early modern period, see Valeria Finucci, The Manly Masquerade: Masculinity, Paternity, and Castration in the Italian Renaissance (Durham: Duke University Press, 2003); Patricia Simons, The Sex of Men in Premodern Europe: A Cultural History (Cambridge: Cambridge University Press, 2011).

39 See Bargagli, Dialogo de' Giuochi, p. 61. 
as an androgynous lower body in which the masculine symbol of the pestles dominates the feminine symbol of the pumpkin.

Carnivalesque youth rituals allow us, therefore, to examine the relationship between the Sienese academicians and noblewomen in a broader contextone that reveals the dynamic relationship between misogyny and philogyny. The philogynous facet of the academy is usually deduced solely from 'early sixteenth-century Humanism and its pro-feminist sensibility'. ${ }^{40}$ The embedding of the Intronati's philogynous discourse in carnivalesque contexts, however, makes it necessary for us to consider this aspect of the academy through the prism of traditional fools' societies. As a company of bachelors in transition from boys to adult married men, it is only logical that carnivalesque fools' societies were charged with creating festive and ludic spaces in which their members could approach young girls who could potentially become future spouses, which shows us the ritual origins of the special attention paid to women by the young Intronati. In the liminal spaces of carnivalesque entertainment, fools' companies uniting unmarried young men also expressed their collective attitude to the patriarchal institution of marriage. This occurred in two different ways. While carnivalesque fertility rites performed at wedding celebrations by fools' companies projected a positive image of marriage and served to affirm young males' availability on the marriage market, charivaris performed by the same young men simultaneously stigmatised negative images of marriageill-assorted couples, husbandly impotence, or the submission of men to their wives-as deviations from reproductively successful and male-dominated models of the conjugal state. Charivaris supported normative marriage by revealing negative instances of it. ${ }^{41}$ These performances of carnivalesque folly were based on the dialectical relationship between the laughter of inclusion and the laughter of exclusion; between unmarried youth as subjects of laughter and deviant married couples as objects of derision.

Following the thread of carnivalesque youth rituals, we are led more deeply into an understanding of the Intronati's origins, of their emblem's meaning, and of the structure of their famous comedy. One Sienese historiographic source deserves special attention because of the relationship it demonstrates between the carnivalesque folly of youth, gender play that includes crossdressing, and marriage. The Latin chronicle by clergyman Sigismondo Tizio describes a wedding celebration that took place in 1519 during Carnival:

\footnotetext{
40 Alexandra Coller, 'The Sienese Accademia degli Intronati and its Female Interlocutors', The Italianist, 26 (2006), p. 227.

41 See the socio-anthropological work on fools' societies referred to in note 29.
} 
Die interea eadem nuptie Julii Angeli Benassai, juvenis Senensis, celebrate sunt. Vespere diei sex juvenes ad eas accessere genitalia hominum membra ex subere confecta, plumbo testibus intromisso, ut in tabula posita protinus erigentur et starent; probrosa alia et obscena iuvenes illi personati ibidem admiserunt; priapos dabant puellis et vestibus eorum appendebant.

Meanwhile on the same day [29 January 1515] the wedding of the young Sienese citizen Angelo Benasao was celebrated. In the evening six young men barged in on the feast. They fabricated phalluses made of cork, with lead in the testicles, so that they sat erect when placed on the table; these masked youngsters did other obscene and shameful things. They gave priapi to young girls and hung them on the girls' clothes. ${ }^{42}$

I begin my commentary of this rather laconic fragment and its myriad details with the number of performers - six - which is interpreted by Leo Kosuta as a sacred number for carnivalesque fraternities and which will, a few years later, be the number of juvenes to found the Academy of the Intronati. The source does not spell out what kind of mask or covering the boys wore, so we cannot be sure that they donned fool's caps, but the phallic devices the boys carried allow us to consider this carnivalesque performance a fools' play. ${ }^{43}$ We can only approach the original meaning of the youth ritual (given its transformation in the moralistic commentary of a clergyman) if we consider the phallus as a multivocal and multifunctional ritual symbol characteristic of liminal performance. ${ }^{44}$ The cork phalluses function here in a number of ways. First, they are symbols of masculine power that serve the institution of youth power in a festive context, opposing it to the patriarchal power of the official wedding celebration. Second, they are symbols of male bonding that also contribute to the growth of the phallic community, which would acquire new members

42 This testimony is part of the unedited chronicle of Sigismondo Tizio, Historiae senenses (t. vir. £ 333). It was reproduced in Paolo Piccolomini, La vita e l'opera di Sigismondo Tizio (1458-1528) (Siena: Lazzeri, 1903), p. 26, and is quoted in Kosuta, 'Notes', p. 131, n. 63.

43 For the phallic sceptre and other phallic attributes, I refer to the abundant late medieval and early modern iconography of the fool. For the original phallic form of the fool's cap and its subsequent modifications, see the analysis by Claude Gaignebet and the graphic evidence he presents in A plus hault sens: L'ésotérisme spirituel et charnel de Rabelais (Paris: Maisonneuve et Larose, 1986), II, pp. 213-16.

44 See Victor Turner, 'Liminal to Liminoid in Play, Flow, and Ritual: An Essay in Comparative Symbology', in From Ritual to Theatre: The Human Seriousness of Play (New York: PAJ Publications, 1982), pp. 21-23, 27. 
from the boys present at the feast. Third, they express two different forms of conjunction between the masculine and the feminine: detached from boys and appended to girls' dresses, the phallic attributes symbolise gender fluidity related to the liminal status of youth. Placed in a girl's hands, the phallus becomes a priapic object. It translates the sexual ambitions of the boys and projects the young people present at the wedding celebration into their future as married couples.

In the context of this carnivalesque youth ritual, the oppositions folly/ wisdom and feminine/masculine that determine the structure of the Intronati emblem acquire the transformational potential of rites of passage that folklorists and anthropologists have discovered in riddling. ${ }^{45}$ The conjunction of masculine and feminine symbols on the Intronati's riddle emblem can be interpreted in two different ways: as a hermaphroditic image of youthful gender fluidity and as an androgynous image of marriage leading to adult status. To conclude: the ludic performance of the emblem as a riddle with a double solution enables the Intronati to appear both as an intellectual community of humanist litterati and as a fools' company - a liminal group of young men in ritual transition from boyhood to adulthood.

\section{3}

\section{The Intronati in Gl'Ingannati}

Having examined the broader intellectual, social, and ritualistic context in which the Intronati arose, we now turn to the collective expression of this company in one of its first and most famous comedies: Gl'Ingannati. The play was first performed in the Sala Grande of the Palazzo Comunale on the last day of Carnival, 1532 (or 1531, for the sixteenth-century audience, because Siena's year began on March 25 as per the calendar ab incarnatione). Gl'Ingannati was published in 1537 and constitutes the first public manifestation of the academy in the medium of print; the first edition was decorated with the Intronati emblem. ${ }^{46}$

45 See Don Handelman, 'Traps of Trans-formation: Theoretical Convergences between Riddle and Ritual', in Untying the Knot: On Riddles and Other Enigmatic Modes, ed. by Galit Hansen-Roken and D. Schulman (New York: Oxford University Press, 1996), pp. 37-61.

46 Comedia del Sacrificio degli Intronati (s.l., s.n., 1537). The confusing title of this publication that includes Gl'Ingannati is due to the other burlesque text appearing with it: $I l$ Sacrificio d'Amore, which was performed by the Intronati at the beginning of the same Carnival season. Quotations of our comedy are from Nerida Newbigin's online edition, which is based upon the 1534 manuscript: Ingannati: Commedia degli Intronati recitata 


\subsection{Prologo's Riddle}

I will forego a summary of the play's intricate plot for three reasons. First, the play lacks originality, its formulaic structure being characteristic of sixteenthcentury Italian comedy: beginning with the separation of family members and young lovers, the narrative leads us through a series of challenges and twists of fortune to end with the stability of family reunion and marriage. Second, I wish to avoid the inevitable simplifications that occur when transposing non-linear dramatic action into a narrative. Last but not least, I mirror the approach that is taken by the play itself via the ostentatious refusal of Prologo, the character who introduces the play to the audience, to provide an argomento - the standard introductory plot description that would normally facilitate an audience's understanding of the intricate plot about to be performed. ${ }^{47}$ This omission is quite unusual for sixteenth-century comedy, which almost always included both a prologo and an argomento. As we shall see, the absence of the latter can be understood as part of the play's riddling strategy and as significant for the onstage performance of gender that follows.

At the outset of the play, Prologo appears and presents himself to the audience as the ambassador of the Intronati. ${ }^{48}$ We can assume that this academy member wore some kind of fool's disguise since he stresses his extravagant dress, explaining that it reflects the purpose of the Intronati, which is to perform a comedy. ${ }^{49}$ In this opening speech he explicitly refers to the society's emblem, stating that the comedy emerged from no source other than the

ne' giuochi publici del carnivale in Siena (http://www-personal.usyd.edu.au/ nnew4107/ Texts/Sixteenth-century_Siena_files/IntronatiIngannati.pdf). English translations of the text are from The Deceived, in Five Comedies from the Italian Renaissance, trans. and ed. by Laura Giannetti and Guido Ruggiero (Baltimore: John Hopkins University Press, 2003), pp. 205-84. Page references to these editions (Italian and English) are given in parentheses after each quotation.

47 'Non vi aspettate altro argumento perché quel che ve l'aveva a fare non è in ponto. Fatevi senza, per ora' (p. 6); ('Now that I think about it, don't expect any explanation of the plot, because the person who was supposed to do it isn't up to it. For now you can do without an explanation', p. 209).

48 'Questi Intronati [...] m'hanno spinto qui per imbasciatore, oratore, legato, o procuratore o poeta' (p. 3); ('These Intronati [...] shoved me out here as their ambassador, orator, legate, lawyer, or poet', p. 206).

49 'Io vi veggio fin di qua, nobilissime donne, maravigliare di vedermivi così dinanzi in quest'abito [...] come se noi avessemo proprio a farvi qualche comedia' (p. 3); ('I can tell even from here, most noble ladies, that you are amazed to see me here before you in these clothes $[\ldots]$ as if we were about to present some comedy to you', p. 206). 
Intronati's 'industrious pumpkin' ${ }^{50}$ This statement, which attests to the collective authorship of the Intronati, also implies a playful attitude of the authors towards their audience. We cannot be sure to which aspect of the pumpkinthe symbol, we recall, of the collective head of the Intronati-Prologo is referring: folly or wisdom. By emphasising that the comedy arose from the same pumpkin the Intronati used not only as their symbol but also as a prop in the guessing games they organised for the night of the Befana, ${ }^{51}$ Prologo leaves this riddle's solution to the audience.

In his introduction, Prologo also establishes a playful relationship between male and female. His speech's basic gendered strategy-one that occurs in the prologues of numerous Intronati comedies-consists of clearly dividing the audience into two parts: women and men. The interaction of Prologo with men in the audience is based on masculine notions of cooperation and competition, while his interaction with women in the audience is based on seduction. Men are addressed as potential holders of knowledge, their vision of the comedy oriented towards the all-male world of dramatic production. This is an echo of the earliest Intronati prologue (to the play Prigioni based on Plautus's Captivi), in which male spectators are cast as members of an intellectual community that can 'see the comedy in Plautus' — that is to say, a community of readers that has access to and familiarity with the Latin original. ${ }^{52}$ The Intronati consider men either to be learned (and severe) critics of dramatic production or to be ignorants who are invited to join the academy in order to acquire the intellectual vision they are lacking. ${ }^{53}$ The Intronati's Italian

5o 'La favola è nuova e non altronde tratta che de la loro industriosa zucca, onde anco la notte di beffana si cavaro le sorte vostre' (p. 4); the loose English translation modifies the literal meaning of this statement by substituting 'industrious pumpkin' with 'fevered brains': 'The story is new and not taken from any other source outside of their fevered brains - the same place where on the night of the Befana they decided your fate' (p. 207).

51 See Laura Riccò, Giuoco e teatro nelle veglie di Siena (Roma: Bulzoni, 1993), pp. 72, 170.

52 'La commedia, la quale e fatta solo per voi Donne; gli uomini se la potran vedere in Plauto, donde costoro [gl'Intronati] l'hanno tratta' ('the comedy, which is made only for you Women; men can see it in Plautus, from which it was drawn [by the Intronati]'). IPrigioni di Plauto tradotti da l'intronati di Siena, ed. by Nerida Newbigin (Siena: Accademia degli Intronati, 2006), p. 6.

53 'Oh, poveri uomini. Dove li conduce la loro ignoranza [...] ma questi cotali venghino all'Accademia, ove gli faremo vedere a voler dar giudizio di simil cose'. Comedia intitolata Alessandro del signor Alessandro Piccolomini. Con duo prologi, non più impressi, e composti dal medesimo Autore per la prima e per la seconda volta chè stata recitata in Siena (based on the undated Ruffinelli edition and Ms Escorial Iv.b.12 / Est. 16.5), 2010: http://www-personal.usyd.edu.au/ nnew4107/Texts/Sixteenth-century_Siena_files/ 
adaptation of the Plautus comedy, however, is instead addressed to women. Women are not invited into the all-male academy to learn how to write and to stage a comedy, however. Instead, they are encouraged only to enjoy the product of the Intronati's phallic pestles - that is to say, the performance of the carnivalesque comedy on the public stage, an entertainment that is conceived especially for female eyes and for their pleasure. The Intronati use both explicit statement and punning suggestion to make clear that their comedy is aimed exclusively at women. In Gl'Ingannati, at first it seems that Prologo does not see any men at all when he first appears on stage ('I see you from here, most noble ladies', see note 49), and he continues for some time to address only women. The joking masculine discourse of the prologue abounds in sexual innuendos that establish a metaphorical relation between 'making a comedy' ('farvi [alle nobilissime donne] qualche comedia') and making love. The commedia is offered to its female audience not only as food good for pregnancy but also as representative of the male organs of the Intronati themselves: women are asked to evaluate, while watching the comedy, the size of the authors' ingegni. ${ }^{54}$ By insisting on the pleasure that the comedy — an entertaining product of phallic pestles - is intended to provide its female audience, the Intronati conceive the dramatic experience of women in explicitly erotic terms.

When the Intronati finally address their male audience, towards the end of Prologo's speech, they exclude any possibility of homoerotic allusions: 'As far as the men in the audience are concerned, we really don't care whether they like it or not.'.5 This does not mean, however, that their speech strategy excludes male spectators from the erotic interaction. In order to create the conditions for this interaction, Prologo formulates what sounds like an enigma for men, pointing out paradoxically that

PiccolominiAlessandro.pdf, pp. 8-9 ('Oh, poor men. Where they are driven by their ignorance $[. .$.$] but these men should come to the academy, where we will make them see how$ to want to judge/give judgment of such things').

Gl'Ingannati, p. 4; The Deceived, p. 207. The sexual metaphor of ingegno is widespread in the academy's playful texts and is here intimated as follows: 'Ditemi [Donne] per vostra fé: che credete però che e' voglino [gli Intronati]? E' non chieggono e non domandano altro da voi che la grazia vostra e esser amati da voi (oh, è però questa così gran cosa?) e che voi cognosciate l'ingegni loro (e chi l'ha grosso e chi l'ha sottile)' (p. 5); ('Tell me, honestly [ladies] what do you think they [the Intronati] really want? They aren't looking for anything from you beyond your graces, and when you come to know their penetrating wit—whether it be large or small—you can say “I like this” or “I don't like this"', p. 209). 'Agli uomini non importa che la piaccia o no' (p. 4). 
l'Intronati hanno ordinato un modo che nessun di loro [uomini] la potrà né vedere né udire, se già non è cieco. E però, se qualche sacciuto maligno, tirato dal desiderio che egli had'appontarci, avessi pure una gran voglia di vederla o udirla, cavisi gli occhi, altrimenti (io glielo dico prima) e' non la corrà. Io so che vi parrà strano che i ciechi la veghino, e pur sarà vero; e intendarete come, se voi arete tanta pazienzia ch'io vel mostri. (p. 5)

The Intronati have ordered that none of them [men] may see or hear this [comedy] unless they're already blind. Still, if there's some stuck-up scumbag of a man, drawn by an uncontrollable urge to criticize us, who is here and who really wishes to see and hear it, he'll have to cut out his eyes if he wants to understand it. I imagine you think it's strange that only blind men should watch this comedy. But it's true, and if you just have a little patience you'll understand it, for I'll show you why. (pp. 207-08)

The enigma's solution, for men, is given by the riddling Prologo in the following sentence, which is addressed to women. It is this sentence that establishes a relationship between the male and female audience members:

Come volete voi [donne], adunque, che costoro [uomini] stiano a mirar scene o comedie, o sentino, o vegghino cosa che noi [Intronati] facciamo, o diciamo, essendoli voi [donne] dinanzi? Che più bel giuoco, che più bello spettaculo, che cosa più piacevole o più vaga si può veder di voi? Certo, nissuna. Eccovi adonque mostro come gli uomini non vedranno né udiranno questa comedia, se non son ciechi [...]. Ma voi, donne, la vedrete ed udirete benissimo perché, in vero, non vi cognosciamo così cortesi che vi siate per perdervi o per uscir di voi stesse nel mirarci. (p. 5)

How do you imagine men could come here to marvel at scenes or comedies, or to listen or to watch what we do or say, with you beautiful women here before them? What more beautiful game, what more beautiful spectacle, what more pleasing or beautiful thing could a man see than you ladies? Nothing, certainly. So now I have shown you why men may not see or hear this comedy unless they are blind [...]. But you ladies will see and hear it just fine because we know you well enough indeed to know that you're too well-mannered ever to get carried away or lose self-control from looking at our beauty. (p. 208)

By deflecting the male gaze from the comedy performed by men and orienting it towards the female audience, the Intronati produce more than a paradoxical 
joke for men and a compliment for beautiful ladies. Playfully suggesting to men that comedy performance is an occasion to satiate their eyes with the sight of the beautiful young women present in the theatre enables Prologo to generate erotic tension and 'friction' on the heterosexual axis of visual interaction with the effect of erotic pleasure. This rhetorical strategy is of course based upon the spatial convention of gender segregation in Renaissance theatres: young, beautiful, and noble women occupied the first tiers of the theatre while men were positioned behind them. ${ }^{56}$ The Intronati thus establish, in the prologue, a heterosexual mode of visual interaction in the theatre: women should look at the men on stage (the Intronati), and men (both actors and spectators) should look at women in the audience. ${ }^{57}$

Curiously, this unambiguously heterosexual visual strategy on the level of actor-audience interaction is structured analogously to the ambiguous crossdressing figure that will appear in the space of the dramatic action. In the theatre, real women are placed between two groups of real men: actors and spectators. In the double cross-dressing on stage, the fictional female character is positioned in the performative space between the male body of the actor and his male dress. How does this structural affinity between two apparently opposed theatrical strategies - one separating gender categories and the other blurring them-condition the comedy's performance?

In order to answer this question, I will begin by looking beyond the formal division of this comedy (and of Renaissance comedy in general) into five acts. While this division is relevant as an indicator of the erudite play's revival of the classical tradition of Roman comedies, its structure is not pertinent to the survival of a residual 'fools'-play' stratum that was influenced by both festive ritual and medieval dramatic forms of carnivalesque plays on the Renaissance stage. This approach enables us to reveal another, deeper structural principle of Gl'Ingannati, namely its tripartite configuration of a rite of passage composed of three phases - separation, liminality, and reintegration - that underlies our fools' play and conditions the arrangement of its enigmatic images.

56 Günsberg, p. 63 .

57 In the prologue of another collective work by the Intronati, Amor costante (1540), which was signed by Stordito Intronato (Alessandro Piccolomini), the academicians stress the visual abilities of women spectators in particular, playfully remarking that without their visual attention the comedy risked invisibility. See the online edition revised by Nerida Newbigin in 2010: http://www-personal.usyd.edu.au/ nnew4107/Texts/Sixteenthcentury_Siena_files/PiccolominiAmorCostante.pdf, pp. 7-8. 


\subsection{Separation}

In the two initial scenes (I. 1 and I. 2$)^{58}$ that, I argue, constitute the first part of this tripartite 'rite of passage' play, the Intronati display the older generation on stage but evoke the younger by keeping it entirely absent. The play begins with the entrance of two old friends, Virginio and Gherardo, who have just concluded a marriage contract that benefits both of them: Lelia, Virginio's young and beautiful (but poor) daughter, should marry the old (but rich) widower Gherardo. Virginio's situation as pater familias is complex: his son has disappeared, some years earlier, and thus old Virginio seeks to use his daughter as a means of replacing the feeble masculine potency of his family with the virile financial potency of her future husband.

From the very beginning of the play, the Intronati also confront their audience with an image that stands, in mythological and literary tradition, for a dark and unanswerable enigma: the labyrinth. Gherardo characterises his own situation with the help of this metaphor, asking Virginio to help him out of the intricate labyrinth where he walks as if blind: despite the matrimonial arrangement he has with Lelia's father, the old man cannot manage to see his fiancée, who somehow constantly escapes his sight. ${ }^{59}$

In this first section of the play, the Intronati's representation of old men as foolish theatrically re-enacts the real ritual of young fools staging a charivari to stigmatise the folly of an ill-matched couple, providing an image of what we might well recognise as a mock or grotesque wedding. ${ }^{60}$ Behind the marriage preparations that the characters discuss, we can therefore easily espy a biting

58 Roman and arabic numerals refer throughout to act and scene, respectively.

59 'Fa' adunque, Virginio, se desideri in questa cosa farmi piacere, com'hai detto, che quanto più presto sia possibile si faccino queste benedette nozze; e cavami una volta di questo così intricato laberinto nel quale non so come disavvedutamente sonno incorso' (p. 7). In this modern English translation, the highly significant image of the labyrinth disappears, to be replaced with the much less resonant term 'mess': 'Virginio, if you want to make me happy, as you've promised, let's arrange this holy matrimony and get me out of this hopeless mess that has somehow overwhelmed me' (p. 210).

6o The literary, dramatic, and iconographic motif of the 'grotesque wedding', which was widespread in fifteenth- and sixteenth-century European culture, is an artistic transposition of the charivari ritual performed by male youth. See Jean-Claude Margolin, 'Charivari et mariage ridicule au temps de la Renaissance', in Les fêtes de la Renaissance, ed. by Jean Jaquot (Paris: Éditions du CNRS, 1975), III, pp. 579-6o; Walter S. Gibson, 'Verbeeck's Grotesque Wedding Feasts: Some Reconsiderations', Simiolus: Netherlands Quarterly for the History of Art, 21.1/2 (1992), pp. 29-39; for literary stagings in German and French narrative texts, see my article 'Groteske Ehe in der Frühen Neuzeit und ihre medialen (Re-)Inszenierungen', Zeitschrift für Germanistik, NF 3 (2004), pp. 476-90. 
satire. It is not male bonding through the possession and commodification of a woman's body, as stressed by contemporary critics of the play_inspired by the ideas of Lévi-Strauss and Gale Rubin ${ }^{61}$ — that provokes the Intronati's mockery. On the contrary, the young academicians totally adhere to the fantasy of physical and symbolic sharing of the female body that is part of their juvenile masculine poetics, as displayed in their other bawdy and playful texts. ${ }^{62}$ The Intronati act here not so much as social critics but as representatives of young men and their sexual and marital ambitions. The marriage transaction that is concluded between these two old friends is disruptive because it allows the older generation to secure their own masculine performance in marriage by substituting sexual impotency with financial potency. This gives them the opportunity to rival young, sexually potent (but financially poorer) men and creates an inappropriate age discrepancy between the wedding partners. It is thus unsurprising that the two initial scenes of the play are full of jokes and innuendo that reveal the sexual impotency of both old men, who try to affirm themselves with sexual bravado but appear only as old fools. The foolishness of old men, their lack of sexual potency, and their blindness are thus intimately interrelated in this first section of the play, which is entirely focused on the question of masculine performance in matrimony. ${ }^{63}$

Transgressive and deficient marriage between an old impotent man and a young beautiful woman is only one of the two images of the marital bond that the Intronati introduce to their audience at the very beginning of the play. While the girl remains absent from the sight of her future husband (as well as from the stage) in the following scene, her interests are represented through her nursemaid Clemenzia, an elderly woman who continues the enigmatic discourse of the play in the form of a dream (I. 2). Clemenzia tells her master Virginio that the night before she dreamt of a cat that, playing with a mouse, broke a bottle of wine. This ambiguous dream image, which is based on sexual symbols, is understood by both as a 'sign of marriage' ('segno di nozze', p. 10), but is interpreted in two different ways. While Lelia's old father, who shares the masculine blindness of his old friend, imagines that the dream is a sign

61 And first, of course, by Günsberg, in Gender and the Italian Stage, whose interpretation is discussed above. For discussion of the present scene, see p. 32.

62 See, for example, the priapic dialogue written in 1527 by founder of the Intronati Antonio Vignali, La Cazzaria, ed. by Pasquale Stoppelli, introd. by Nino Borsellino (Rome: Edizioni dell'Elefante, 1984).

63 On the anxious relationship between male potency, generative capacity, and masculine cultural power in early modern culture and on the Renaissance stage, see Finucci's insightful study, The Manly Masquerade. 
of the transgressive marriage he has arranged for his daughter and Gherardo, the nursemaid suggests another solution-one that would be socially normative and would satisfy the ambitions of the younger generation. That is, Lelia should marry a young man who would be able to provide her with both sexual pleasure and children. At the beginning of the play, therefore, the Intronati confront their audience with an image of marriage that is conceived as a riddle with two different potential solutions: one imagined by men and the other suggested by a woman. In Bargagli's riddling-game terms, while the men imagine una cosa poco onesta, the woman visualises a convenevole cosa. This double image of marriage-represented through the labyrinth and the dream, and predicated upon the conflict between the older and younger generationspresents itself as a riddle because of a block element it contains. ${ }^{64}$ This element is the absence of the young girl who is hidden from our sight and the absence of the young boy who would ideally suit her as a husband. What is worth noticing here, for the further development of the dramatic action, is this initial contraposition of the men's blindness in the labyrinth of their illicit desires with the clairvoyance of the woman's capacity for prophetic dreaming.

If we consider this enigmatic interaction from the perspective of the rite of passage - and, more precisely, its first separation phase — we might notice that the two opening scenes, by putting forward the tricky question of marriage, develop the theme of children's separation from fathers. ${ }^{65}$ Virginio's son (Lelia's brother, the young Fabrizio) is declared missing and is mourned as the missing link in the patriarchal continuity of the family; his daughter Lelia is absent from the sight of her father, the patriarch, and of her future husband. The fact that both Lelia and Fabrizio are also absent from the sight of the audience in these two initial scenes is significant for the next phase of the play.

\subsection{Liminality}

In the opening scenes of Gl'Ingannati, the Intronati playfully confront their audience with two different understandings of the conjunction of masculine and feminine: the marital union that is planned from the outset, on the one hand, and the gender fluidity of youth that follows from the separation of

64 Enygmatology defines a block element as 'the element which impedes solution of the riddle question', thus a 'block' to the solution that is a 'central notion in riddling. Thomas A. Green and W.J. Pepicello, 'The Riddle Process', Journal of American Folklore, 97.384 (April-June, 1984), p. 189.

65 Although I don't discuss here the issue of separation in Gl'Ingannati as a literary motif in its multiple relations to ancient drama and romance, or to vernacular literary and folkloristic sources, this topic is explored by Cerreta in the introduction to his edition of the play. 
individual from family structure, on the other. Act I scene 2 offers the audience a new riddle via the monologue of a male actor dressed as a boy but speaking as a girl, who enters indirectly, asking the viewers to guess whether they see a boy or a girl:

Leaving the house alone at this hour requires real courage when one considers the evil ways of the rowdy young men of Modena! Oh, it would serve me right if one of those young rogues forced me into one of these houses to see for himself whether I was a boy or a girl! (p. 214)

In the Italian original, the speech of this male actor in male apparel is grammatically marked as feminine:

Gli è pure un grande ardire il mio, quando io 'l considero, che cognoscendo i disonesti costumi di questa scorretta gioventù modanese, mi metta sola in quest'ora a uscir di casa! Oh, come mi starebbe bene che qualcun di questi gioveni scapestrati mi pigliasse per forza e, tirandomi in qualche casa,volesse chiarirsi s'io son maschio o femina! (p. 11, my emphasis)

I would argue that this performance of gender ambiguity arises as liminal from the anthropological opposition between young and old: as we can see from the negative mention of 'young rogues', the allusion to rape, and the lesson the character should learn from the danger of being raped, this performance develops within the framework of the social opposition of norm and transgression. (We shall see, too, that this opposition will be further transposed into the moral categories of honour and shame, and will lead us back to the allegorical images of wisdom and folly - all of which were, of course, commonplace binaries in late medieval and early modern discourse.) It is particularly significant that riddle's solution is provided not by men (who are presented here as deviant 'young rogues' who might discern sexual invitation-or cosa poco onesta -in the appearance of a figure met alone in the street at an unusual hour) but by women who incarnate moral vision and who are able to find a decent explanation-or convenevole cosa.

After producing her mysterious and gender ambiguous effect on the audience, the figure explains that she is Lelia and is pursuing an honest marital purpose. She has escaped from the convent where she was locked during the preparations for her marriage and she has disguised herself as a male servant (Fabio) in order to win back the young lover who had abandoned her for another young girl (Isabella, Gherardo's daughter). Lelia claims that all she, an 
honest unmarried woman, wants is to see the object of her love. ${ }^{66}$ By providing the audience with the solution to the riddle of her appearance, Lelia introduces the first part of the argomento that was hidden by the Intronati in their prologue. This decent explanation of the cross-dressing performance is given in monologue form to the audience and in dialogue form to the clairvoyant nursemaid Clemenzia, who is reintroduced in this scene in order to recognise Lelia behind the appearance of the young man met by chance in the street.

As noted above, recent scholarship reads double cross-dressing performance as an imaginative field with numerous sexual possibilities. Yet these illusory sexual alternatives, as projected by the onstage construction of ambiguous gender, can be reduced to only two social options: normative and transgressive. Lelia's wise speech - which provides the solution to the riddleformulates the social norm of licit sexuality that is possible only within the marital bond. In scenes where Lelia encounters new characters who cannot discern her identity, however, the Intronati perform folly via a series of transgressive visual images. To the 'rowdy young men' in the street, Lelia could appear as someone who would like to be raped-either as an adolescent boy (object of homoerotic desire) or as a young woman (object of heterosexual desire). Before Clemenzia recognises Lelia, the nursemaid believes that she is being sexually assaulted by an anonymous boisterous boy. And even after revealing Lelia's identity as a woman in men's clothes, Clemenzia labels the young woman as disorderly. Given that she leaves a convent in masculine disguise, Lelia evokes the image of a nun of loose morals pursuing sexual pleasure; when appearing in men's clothing in the street, she further suggests the image of a female prostitute who attracts her clients by rivalling male representatives of the same profession. ${ }^{67}$ Through this suggestive performance, the Intronati stimulate the sexual fantasies of young men in the audience (who, in reality, did not have access to upper class women before marriage), exposing to these viewers a young girl from a good family who might tantalisingly appear as sexually available. ${ }^{68}$ In her interactions with her unfaithful lover, Fiamminio, and his new fiancée, Isabella, Lelia appears simultaneously as Fiamminio's potential male lover, serving him not only at table but also in bed, and as a friend who betrays him by trying to seduce his beloved. For an audience that already

\footnotetext{
66 '... senza altra speranza che di poter saziare questi occhi di vederlo un dì a mio modo' (p. 11); ('without any other hope that to satisfy my desire to see him one day at a time', p. 215).

67 See the analysis of this scene by Giannetti and her references to work by social historians of the early modern city, in Lelia's Kiss, pp. $5^{1-53}$. 
knows both the sex of the actor and the sex of the character, Lelia/Fabio could provoke both male-male and female-female desire. More specifically, in the kiss our double cross-dresser gives to Isabella, the audience could see an illicit kiss between either two female characters or two male actors behind the normative heterosexual kiss of the young boy Fabio and the desirable Isabella.

According to traditional patriarchal views on sexuality, these suggestive images were at the very least theoretically condemnable and were stigmatised in normative discourses on sexuality and public behaviour (if not prosecuted in court). At this phase of the dramatic action, it remains unclear how this performance of transgression, which is made possible through the destabilisation of visual perception, is related to the normative heterosexual discourse that is developed by the Intronati in their prologue and by their female characters in the first part of the play. This opacity can be maintained because Lelia's riddle, as it turns out, is only the half of the dramatic riddle conceived by the Intronati.

While, in the first half of the play, cross-dressed Lelia substitutes for the missing Fabrizio in her performance of the phantasmatic phallus, from the third act on the same actor who plays the role of Lelia appears on stage as her twin brother, Fabrizio, who substitutes for the sister character in the second half. ${ }^{69}$ This actor's performance in the first half interrogates notions of femininity; in the second, it serves to interrogate and to construct masculinity. With the entrance of Fabrizio, the Intronati introduce two scenes (III. 1 and 2) that have special symbolic status, positioned as they are precisely in the middle of the five-act comedy. According to Andrews, spectators could recognise Fabrizio as 'a real male' from his initial appearance on stage (p. 43). If we share this vision, the meaning of these two scenes, the connection between them, and their function escapes us completely. A more differentiated gender approach that is being developed in recent studies (but that has thus far ignored the central part of the play) constitutes, therefore, an alternative point of departure for my analysis. ${ }^{70}$

69 This performative trick was reconstructed in Andrews, 'Gli Ingannati as a Text for Performance'. Further references to this work appear in the text.

70 I refer here, in particular, to Giannetti's analysis of the construction of masculinity in Gl'Ingannati in the dynamic terms of maturation and 'phallic revelation': Lelia's Kiss, pp. 18-19, 55, 143), and to Milligan's performative approach to masculine identity in Gl'Ingannati. In his analysis of the play, he demonstrates that the 'possessing of the phallus is not enough. For the boy Fabrizio to assume his role of manhood, he must also perform as a man'. See Milligan, p. 34. 
The first scene (III.1) shows Fabrizio coming to Modena, where the Intronati situate the main action of their comedy. Why Modena? ${ }^{71}$ Special attention to 'landmarks and characteristics of the city', as well as 'references to topography and heraldry' prompts Andrews to conclude that 'altogether this is a nicely written scene in a realistic vein' that is significant for the Renaissance poetics of drama (p. 28). Yet we can find a more productive interpretive angle via a symbolic reading of the scene in its relation to the construction of masculinity. Two figures accompany Fabrizio to look for his father during the young man's journey to Modena: a fool, Stragualcia, and a teacher and pederast, Messer Piero (Pedante). This trio suggests to the audience that Fabrizio is not yet a 'real man': the fool indicates the youth's lack of wisdom; the teacher, who is characterised as a 'sodomito', makes his young pupil appear effeminate. ${ }^{72}$ The city to which they bring Fabrizio is evoked as a land of transit or passage (a 'terra' of 'transito'), ${ }^{73}$ suggesting the initiatory nature of the young man's journey.

The city's curiosities are transformed into sexual symbols via a succession of double entendres in the discussion among the three characters. The order in which these symbols appear is not arbitrary. First, the teacher shows the adolescent Fabrizio what is presented as the city's main curiosity: a hermaphrodite on the side of the Modenese cathedral, medieval drollery that can still be seen today and that is known as the potta da Modena.

While the decent interpretation of this name suggests that we understand potta as podestà (chief magistrate), potta is also a euphemism for vulva. ${ }^{74}$

71 Since the collective authorship of Gl'Ingannati by the Sienese Academy of the Intronati is now generally accepted, I will not consider the speculations of earlier scholars who attempted to identify a supposed Modenese author of this anonymous play.

72 In her chapter 'Pedants, Candlemakers, and Boys: Sodomy and Comedy', Giannetti does not analyse Gl'Ingannati. Instead she examines a wide range of Italian Renaissance comedies from the perspectives opened up by the works of social historians Michael Rocke and Guido Ruggiero, who have demonstrated that in Italian sixteenth-century cities, 'in their early to mid-teens young males were often seen as highly androgynous, with feminine looks and manners'. Their historical sources testify to 'a tacit acceptance of passive sodomy when it involved male youth up to about the age of eighteen, apparently because this was seen as a temporary and passive/feminine stage in male development towards adulthood'. Giannetti, Lelia's Kiss, pp. 33, 157.

73 'Pedante: Questa terra mi par tutta mutata poi ch'io non vi fui. Vero è ch'io non vi fui se non per transito' (p. 38, my italics). In the English translation, the second meaning has disappeared: 'This city seems completely changed since I was last here. Actually I was here only briefly' (p. 242).

74 On the linguistic and literary developments of the image of the potta da Modena, see Andrea Lazzarini, 'Il Potta da Modena: Precisazioni storico-linguistiche attorno a un personaggio della "Secchia Rapita” di Alessandro Tassoni', Nuova Rivista di Letteratura 


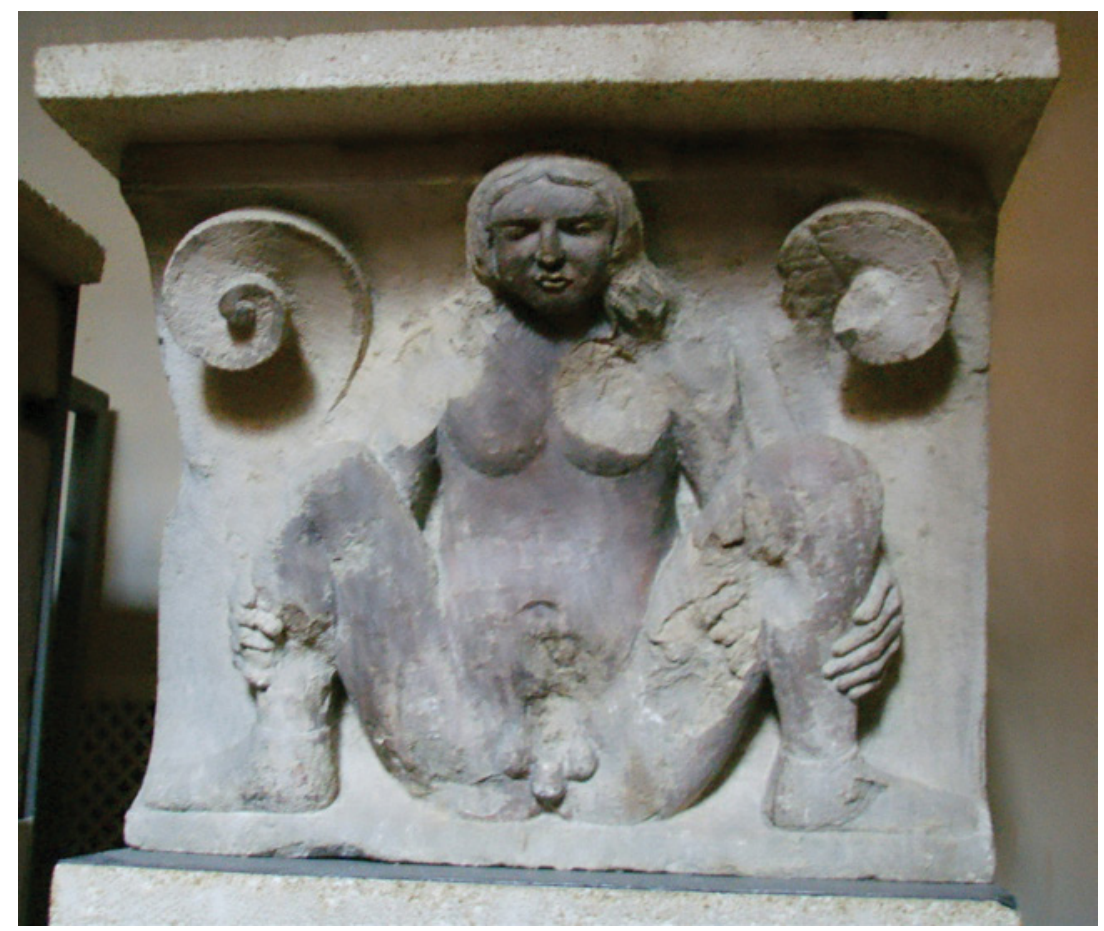

FIGURE 2 Potta da Modena, by Master of the Metopes, (Twelfth century). Modena, Cathedral Lapidary Museum. I. Sailko.

The foolish and ignorant boy does not understand the symbolic reference of this image to his own ambiguous sexual identity as an effeminate boy and his passive, woman-like role. Instead, he bursts into laughter, simplistically seeing the obscene image as nothing more than a joke.

The visitors then examine the Modenese coat of arms, which features crossed drills-phallic symbols that, in their pictorial affinity with the crossed pestles on the Intronati emblem, evoke a phallic community of young men.

Finally, the teacher and the fool discuss the 'most egregious bell tower that exists in the whole structure of the universe $[. .$.$] and whose shadow they claim$

Italiana, 16.1-2 (2013), pp. 61-94. For the relationship between potta and puttana (whore), especially in the context of playful Renaissance pseudo-academic etymology, see Courtney Quaintance, Textual Masculinity and the Exchange of Women in Renaissance Venice (Toronto: University of Toronto Press, 2015), pp. 18-19. 


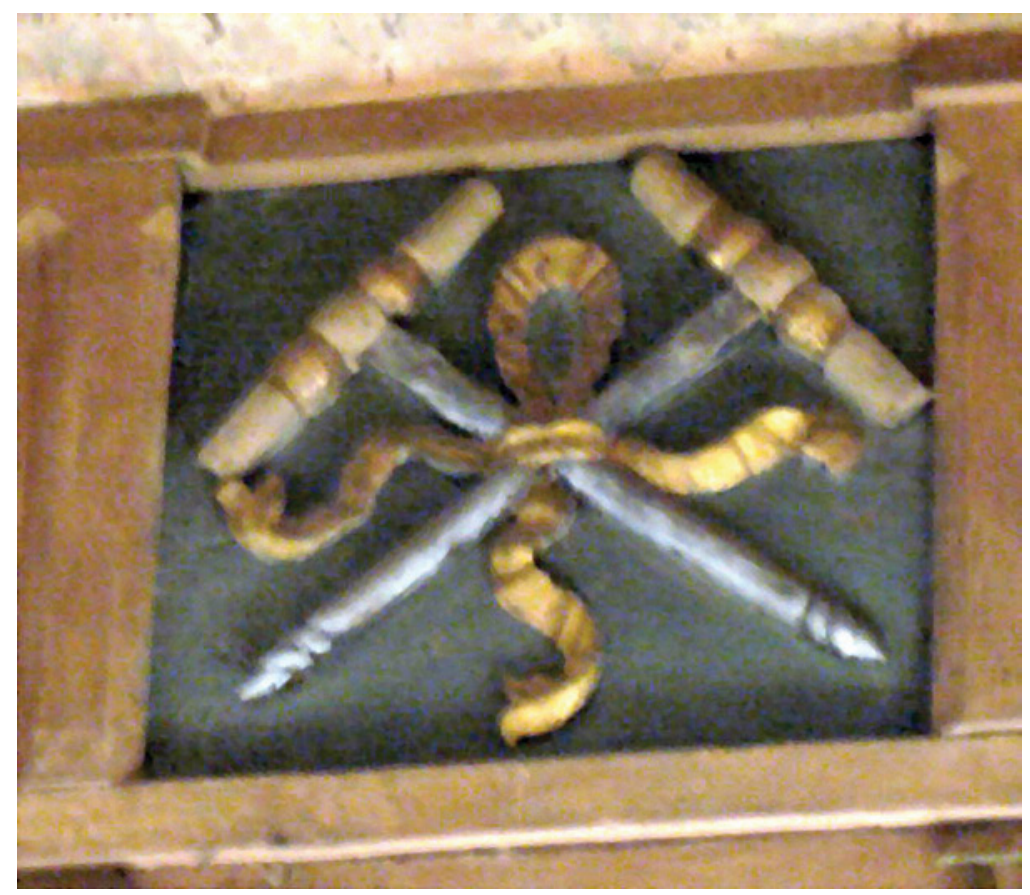

Figure 3 Modena coats of arms, Sala del Fuoco, Palazzo Comunale.

makes a man go crazy,75 projecting the visual experience of this symbol of triumphant virility into the boy's future: 'You will see' ('Tu vedrai'). This scene is clearly not just a 'casual chat' establishing an 'illusion of a real contemporary setting', as Andrews would have it (p. 29). Instead, it is an ideogram of the play's symbolic trajectory that depicts the transformation of an effeminate, foolish boy into a wise and powerful adult man through a succession of initiatory riddles.

The symbolic texture of the Modena landscape allows us to build a bridge to the second scene, which Andrews opposes on the grounds of its 'more "medieval" structure of generalizing symbolism', and which he excludes as an interlude in the comedy's structure. In his view, the scene falls out of the

75 'Pedante: Tu vedrai qui il più solenne campanile che sia in tutta la machina mondiale. Stragualcia: È quello al qual i modanesi volevon far la guaina? E che dicono che la sua ombra fa impazzar gli uomini? Pedante: Sì, cotesto' (p. 39); ('Pedant: There you see the most egregious bell tower that exists in the whole structure of the universe. Stragualcia: Is that one the people of Modena wanted to put a sheath over and whose shadow they claim makes a man go crazy? Pedant: Yes, That's it', pp. 243-44). 
dramatic whole of the play, which otherwise strictly obeys in all its parts 'the mode of dramatic realism' that is characteristic of Renaissance theatrical aesthetics (pp. 32-33). One can object to this claim by referring to the very clearly formulated aesthetic position of the Intronati, who were against spoken interludes and never included them in their dramatic performances. ${ }^{76}$

If III. 2 is not an interlude, then, what is its place in the comedy's structure, its meaning, and its function in the performance? The scene opens with the travellers seeking a place to spend the night and facing a choice between two inns: lo Specchio (the Mirror) and il Matto (the Fool). Andrews insightfully suggests that 'the two inns are not just functional locations in a fictional space: they are also symbolic locations which morally categorise those who pass in and out of them. They assume temporarily something of the character of "mansions" in medieval drama, where the audience would attach a label to a character according to whether he or she came from Heaven or Hell' (p. 32). While the sign of the Fool speaks for itself, the sign of the Mirror is interpreted for Fabrizio by his teacher as follows: 'The Mirror corresponds to wisdom' ('Speculum prudentia significat'). Not only are the characters faced with the choice between folly and wisdom, as 'the whole of humanity is being divided [by two rival innkeepers] into two categories: those who stay at "lo Specchio" and those who patronise "il Matto"' (p. 33). Andrews leaves two questions unanswered, however: what affinity is there between the inns' signs and the 'sophisticated invention of imprese or emblems, which was a common pastime among sixteenth-century courtiers' (p. 31)? And why did the Intronati have their characters opt for il Matto over the patently better choice of the Inn of Wisdom?

The answer to the first question resides in the earliest Intronati emblem, which was composed of the same paradoxical image of wise folly described above, but which included a second motto: sic sapere prudentia est (thus knowledge is prudence). ${ }^{77}$

76 'Intermedi non aspettate in altro modo, che in musiche fatte dentro, che così è stato sempre costume degli Intronati' ('Don't expect interludes in [the comedies] in any mode other than made of music, which is what has always been the custom of the Intronati'). Prologue to L'Ortensio Comedia degl'Academici Intronati rappresentata in Siena alla presenza del serenissimo gran duca di Toscana il di xxvi di gennaio M D L X, online edition by Nerida Newbigin, 2010, p. 8: http://www-personal.usyd.edu.au/ nnew4107/Texts/ Sixteenth-century_Siena_files/IntronatiOrtensio.pdf. This critical edition is based on the editio princeps (Siena: Luca Bonetti, 1571) and takes into account the manuscript conserved in Florence (Biblioteca Nazionale Centrale, Ms Magliabechiano VII.196).

77 See Kosuta, 'Notes', p. 132 for the description, and p. 138 for the reproduction of the emblem. 


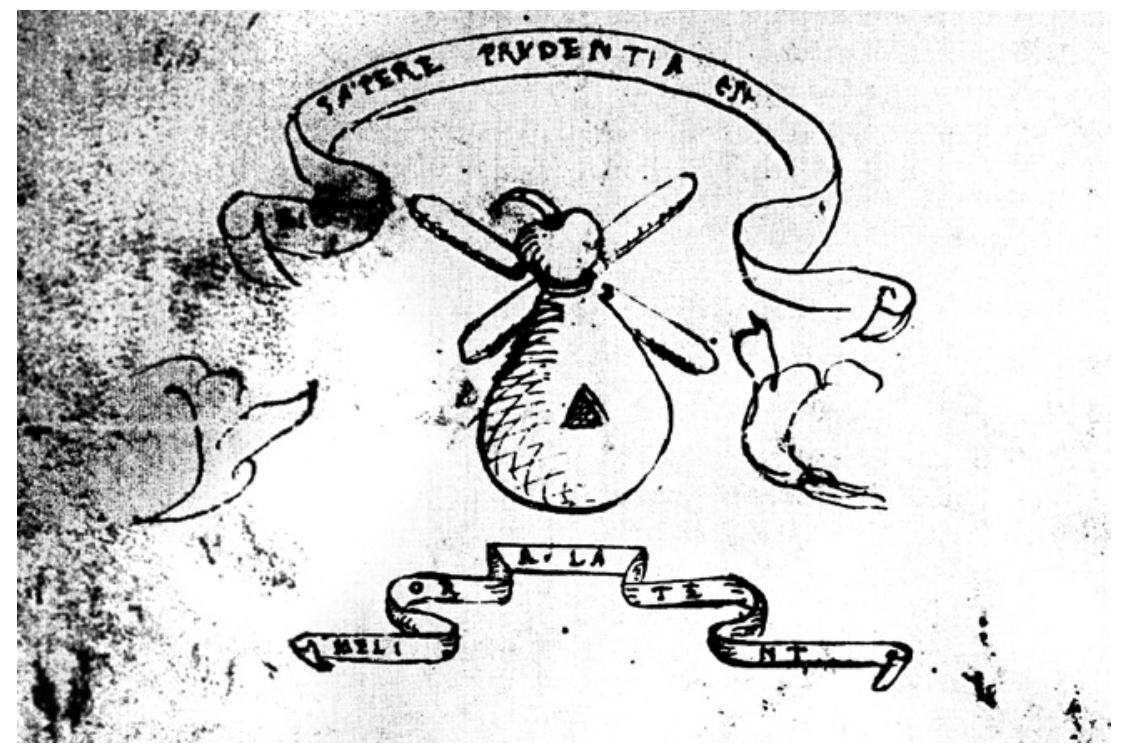

FIGURE 4 Emblem of the Accademia degli Intronati (1533). Drawing. Archivio di Stato, Siena, Consistoro 1003.

In this context, Messer Piero's question to Fabrizio following his Latin interpretation —-Do you understand, Fabrizio?'78 — can be understood in two senses: first, as a playful self-reference by the Intronati to their academy; second, as a formulation of their fools' society's mission to transform silly boys into wise men.

The answer to the second question resides in the late medieval literary and dramatic genre of the fools' play that was imported into Renaissance comedy. By universalising folly in Gl'Ingannati, the Intronati position themselves alongside the cultural tradition of the Ship of Fools, the Inn of the Blue Boat, and numerous other imaginative depictions of the reign of Folly, all of them arising from the ritual and theatrical performances of carnivalesque youth companies. ${ }^{79}$ By permitting folly to triumph over wisdom on stage, act III

${ }_{78}$ 'Pedante: Speculum prudentia significat iuxta illud nostri Catonis "Nosce teipsum". Intendi, Fabrizio?' (p. 40); ('The mirror signifies prudence, according to the proverb of our Cato: “Know thyself"', p. 245.)

79 For Brant's Ship of Fools in the context of European charivari culture, see my 'La procession charivarique en texte et image: Les recueils lyonnais de la chevauchée de l'âne-La Nef des fous de Sebastian Brant—Le Quart Livre de François Rabelais—Les Songes drolatiques de Pantagruel', in Medialität der Prozession: Performanz ritueller Bewegung in Texten 
scene 2 of our comedy demonstrates striking analogies with the late medieval sottie, a satirical-allegorical carnivalesque play that presents to its audience a company of fools who institute a reign of Folly in order to transform everyone into a fool. Even the title chosen by the Intronati, The Deceived, becomes clearer within the context of the titles of sotties performed in late medieval France during the last third of the fifteenth century: Sottie nouvelle des trompeurs (New Fools' Play of Deceivers) or Sottie des sots triumphans quitrompent chascun (Play of Triumphant Fools Who Deceive Everyone) ${ }^{80}$ Although we have no proof that French sotties constituted direct literary sources for Italian comedy, they were 'material floating in the cultural net's1 in terms of their generic pattern, which was common across several European countries, and in terms of their textual and performative tropes, which circulated throughout European theatre in modes that have still to be explored.

The oppositions folly/wisdom, feminine/masculine, and boy/man, which determine the structure of the fools' play in Gl'Ingannati, are actualised when the travellers choose the Inn of Folly. Stragualcia belongs to the inn in his emblematic status of the fool; Messer Piero (Pedante) is sent there as a sodomito who lustfully follows the adolescent son of the innkeeper, who is entering the Matto. Here, the fools' play develops its social satire, rooted in charivari, by placing the fool's cap squarely on the adult who transgresses heterosexual norms, while Fabrizio passively follows his teacher, suggesting his submissive feminine gender role. Instead of stigmatising Fabrizio's folly as a transgression, therefore, the Intronati associate it with youth itself-a temporary status of non-differentiated identity - which makes possible the connection between the fools' play and the liminal phase of the rite of passage.

und Bildern der Vormoderne, ed. by Katja Gvozdeva and Hans Rudolf Velten (Heidelberg: Winter Universitätsverlag, 2011), pp. 323-57. On the relationship between the historical form of the carnivalesque fraternity and the allegorical meanings of the Blue Ship, see Herman Pleij, Het gilde van de Blauwe Schuit: Literatuur, Volksveest en burgermoraal in de late Middeleeuwen (Amsterdam: Meulenhoff, 1979). For an ethnocritical analysis of the Inn of the Blue Ship in Bruegel's carnivalesque painting, see Claude Gaignebet, 'Le combat de Carnaval et de Carême', Annales. Économies, Sociétés, Civilisations, 2 (1972), p. 334.

80 These two titles appear in two different collections containing the same dramatic text. See Recueil Trepperel, ed. by Eugénie Droz (Geneva: Slatkine, 1974), nr. 3; Recueil général des sotties, ed. by Émile Picot (Paris: Firmin-Didot, 1902-1912), III, nr. XIX.

81 See Joachim Küpper, The Cultural Net-Early Modern Drama as Paradigm (forthcoming, 2017). 


\subsection{Reintegration}

The next morning, Fabrizio leaves the Matto. He is now dressed in white, the symbolic colour of masculine initiation, ${ }^{82}$ following the trajectory indicated by the masculinising symbols of Modenese topography. Determined to find his father, he is on his way to reintegrate himself within the family structure as an adult man. He is not a fool anymore, yet to become a man one must be recognised as such by others. Not only is Fabrizio played by the same actor who interprets Lelia, but also his new white costume is the same as the one that had been worn in the first half by cross-dressed Lelia, which is (of course) absent from the stage but present in the spectators' memory. Coinciding in both physical appearance and costume with his cross-dressed twin sister, Fabrizio's performance completes the riddle offered by the Intronati to their audience, inverting the relationship between the cosa poco onesta and convenevole cosa. If, in the first half of the play, the convenevole solution of the riddle was feminine, in the second half this solution would be not only false but also regressive and transgressive, since a grown man must be free of any youthful effeminate appearance.

The fools' play continues by transposing the stigma of folly from young men who have found the way to wisdom onto those who are deceived by Fabrizio's appearance. Characters who mistake Fabrizio for cross-dressed Lelia (or for her alter ego Fabio) are contrasted with Fabrizio, who now affirms his follyless status as a real man and as the son of his father. The former appear to Fabrizio as pazzi (mentally deranged, literally 'crazies') — first among them old Virginio, who takes Fabrizio for his daughter Lelia instead of recognising him as his son, and is therefore the perfect example of a fool-an object of carnivalesque derision. ${ }^{83}$ Trying to leave the liminal space marked both by folly and

82 On white as the ritual colour of male adolescence in Tuscany (and, particularly, Florence), see Trexler, p. 372; Amedeo Pellegrini, 'Per l'arrivo di Cosimo I a Siena', Bullettino senese di storia patria, 10 (1903), pp. 174-75.

83 For the first mention of pazzia in Gl'Ingannati, see III. 5; as associated with carnivalesque derision, see III. 7: 'Fabrizio: Io ho conosciuti molti modanesi pazzi, li quali non contarei per nome, ma pazzi come questo vecchio, che non stesse o legato o rinchiuso, non viddi alcuno mai. Guarda che bello omore! È impazzato in questo (per quanto mi sono accorto) che i gioveni gli paion donne. [...]. E non vorrei per cento scudi non poter contar questa pazzia alle veglie, al tempo dei carnovali' (p. 49); ('Fabrizio: I've known many crazies from Modena, whom I'll not name, but I've never seen any like this old man who weren't tied down or locked up. What a strange humour he's in! He is out of his mind, at least from what I can tell, because he seems to think that young men are young women. [...] And not for a hundred scudi would I want to miss the chance to tell the tale of this madness during carnival', p. 255). 
by the symbolic figure of the hermaphrodite potta da Modena, which reunites the two opposite-sex twins in a sophisticated riddle, Fabrizio does not only act as a test case for adult characters who risk being trapped under the reign of Folly but also is himself exposed to an initiatory test. Mistaken for transgressive Lelia (who escaped from her father) by the two old fools, Fabrizio is locked away in a dark room with another girl, Gherardo's daughter Isabella. The darkness of the room mirrors the obscurity of the riddle to be solved and creates a space for sexual encounter between the two young people. This dark place is a space of testing and transformation; what is hidden from the audience's eyes is represented indirectly through the voyeuristic monologue of the servant who reveals Fabrizio's virility to the listeners.

Recent studies on Renaissance comedy argue that phallic revelation is a means of constructing a heterosexual, aggressive, dominant, and triumphant masculinity. ${ }^{84}$ It is important to stress the exact mode of phallic revelation that is conceived here by the Intronati. It is neither the father nor any other man who reveals the sexual identity of Fabrizio-a mode that would continue to project homosexual fantasies-but a female servant, Pasquella. Her monologue (IV. 5) implements the same heterosexual ocular strategy of the Intronati that was constructed in the prologue for actors and audience members alike, this time in order to make possible the dénouement of the play. Expressly rejecting men in the audience and addressing only women, Pasquella says she wants to share with this female audience her visual experience: she entered the room into which the supposed girl was locked with another girl, only to discover what she calls a 'large pestle' ('pestaglio'). The male organ she sees acquires, in her eyes, the disproportionate dimensions we recall from the central symbolic scene as the dimensions of the bell tower of triumphant phallic masculinity. Humorously stressing its impressive size, Pasquella, witness to the phallic revelation, offers the key (another phallic symbol) ${ }^{85}$ to the room containing the riddle's solution to the female audience, inviting them to join her and to evaluate the pestaglio themselves. In playfully erotic terms, this speech permits the women present to participate in sexual pleasure; in socioanthropological terms, Pasquella's words are a performative act that consecrates the transformation of boy into man.

By performing this transformation on stage, the Intronati fulfill their real ritual mission as a youth society, displaying the right course for young male

84 See Giannetti, Lelia's Kiss, pp. 114, 142-52.

85 Patricia Simons illustrates the pictorial and literary representations of the key as a 'wellknown metaphor for the penis', particularly in Italian carnivalesque songs. See her The Sex of Men in Premodern Europe, pp. 170, 187. 
audience members to follow. Thus men go blind in the theatre only to be revealed as holders of the phallic pestles of masculine potency and domination - created, in a sense, by women who never lose their vision.

Phallic revelation solves not only the riddle of non-differentiated youthful identity but also the riddle of marriage that is presented to the audience at the beginning of the comedy. When Fabrizio, separating himself from his feminine appearance, forms a couple with Isabella, Lelia reveals her true female identity to her beloved Fiamminio in order to be married to him. The comedy, which starts with a transgressive image of a marital union between a too-old man and a lovely young woman thus ends with a normative and harmonious resolution via two marital engagements between young partners that are eventually approved as good matches by the initially reluctant fathers - a decision that reintegrates the old men into social normativity.

In its ritual movement from youth to maturity and from transgression to norm, this carnivalesque fools' play aims at the licit and normative conjunction of male and female, ${ }^{86}$ doing away, at the end, with folly - both in terms of the image of the grotesque wedding projected at the beginning and in terms of the deviant possibilities the play opens up in the liminal space of the crossdressing performance of the youths. ${ }^{87}$ In its ritual logic, the comedy shows us that the enigmatic uncertainty created in the performance of cross-dressing is the 'controlled uncertainty' of public events that, according to social anthropologist Don Handelman, have the same transformative ritual power and modelling social function as do rites of passage. ${ }^{88}$ Revealing analogies between rites of passage and riddles in their shared nonlinear structure and teleology, Handelman defines the latter in their ritual functioning as 'traps of trans-formation's 89

As we have seen, our comedy proceeds via multiple riddles that arise along a youth's path from childhood to maturity and from folly to wisdom. At the same time, the comedy's structure, as a whole, can be described as a single significant riddle that was offered by the learned fools' society to its audience

86 For the anthropological and social significance of the unity of opposites as ritual symbols, see Bourdieu, 'Le sens pratique', Actes de la recherche en sciences sociales, 2.1 (Feb. 1976), pp. 69,70 .

87 In a narrow sartorial sense, the term 'cross-dressing' cannot be applied to the twin brother; however, his feminine performance and his likeness to his cross-dressed twin sister, all considered within the context of the cross-dressing rituals of Sienese young males considered above, allow me to use the term loosely to describe both Lelia and Fabrizio.

88 Don Handelman, Models and Mirrors: Towards an Anthropology of Public Events (New York: Berghahn Books, 1998), p. 66.

89 Handelman, 'Traps of Trans-formation'. 
through Gl'Ingannati's playful handling of two cultural symbols that cannot be clearly differentiated and that fashion, in Renaissance culture, a contradictory field of similarities and oppositions, namely the hermaphrodite and the androgyne.${ }^{90}$ Visually, this enigma is represented by the potta da Modena, a visual sign that remains part of the stage scenery and thus before the eyes of the audience from the beginning to the end of the play, but that changes its meaning as the scenes progress. Apotropaic drollery of the medieval cathedral, the Modenese hermaphrodite is used by the Sienese authors as a symbol of youthful non-differentiated sexual identity that is enacted through crossdressing performance in the liminal phase of the play. This enigmatic figure represents a 'trap of trans-formation' for a young man, menacing him with the threat of regression should he fail to solve the riddle. The riddle's solution, of course, is found at the end in the harmoniously married couples that evoke a non-transgressive instantiation of the androgyne as a Renaissance symbol of Christian marriage. ${ }^{91}$ The discrepancy between the gravity of the religious building and its medieval drollery disappears in the eyes of the Renaissance audience in the moment when the transformation of deviation into norm and non-differentiated masculine/feminine identity into married couple is achieved in the play. It is this heterosexual and normative conclusion that allows the transformation of the monstrous hermaphrodite (which fulfilled an apotropaic function) into the divine androgyne that is represented precisely on the church where the Christian marriages take place.

\section{$4 \quad$ Epilogue}

In its association with the playful enigmatic emblem of the Accademia degli Intronati, Gl'Ingannati has an important self-referential dimension for academy members - in other words, the phallic revelation on stage has a particular

9o For the relation between these mythical images, beginning with their ancient origins to their transformations in Renaissance culture, see Marian Rothstein, 'Mutations of the Androgyne: Its Functions in Early Modern French Literature', Sixteenth Century Journal, 34.2 (2003), pp. 409-37; Kathleen P. Long, Hermaphrodites in Renaissance Europe: Women and Gender in the Early Modern World (Farnham: Ashgate Publishing Limited, 2006); Sophie Comarmond, 'Le mythe de l'hermaphrodite dans la Renaissance', in Métamorphoses du mythe: Réécritures anciennes et modernes des mythes antiques, ed. by Peter Schnyder (Paris: Orizons, L'Harmattan, 2008), pp. 304-05.

$91 \quad$ For hermaphroditic and androgynous imaginings in the comedy that represent one of the major literary sources of Gl'Ingannati, see the chapter 'Androgynous Doubling and Hermaphroditic Anxieties: Bibbiena's Calandria', in Finucci, pp. 189-223. 
meaning for the group of young performers who enact it. While, in the prologue, the actors present the comedy as a riddle that was drawn from their academic pumpkin, in the dénouement they define the triumphant phallus in the comedy's action as a pestaglio in playful reference to the second masculine element of their emblem. Asking women, during the prologue, to verify whether the Intronati's phallic pestles are big or small, they are revealed in all their magnitude, in the dénouement, in the concave mirror of a woman's eye. Through the dramatic enactment of their collective emblem (on which phallic pestles dominate the feminine symbol of the pumpkin), the Intronati thus appear, at the end of the play, as a dominant community of young men, confirming through women's eyes their masculine value. The receptiveness of women's eyes - which are modelled by the Intronati in their prologues, through numerous sexual allusions, as analogous to the vagina-is a necessary condition of the social visibility that the Intronati attempt to obtain in Siena by means of their carnivalesque performances. This liminal group of young Sienese litterati that is obliged to declare in institutional texts their detachment from a world ruled by fathers, projects itself into this same world on festive occasions, parading - through the public performance of the comedy-the power of their youthful academic pestles in a central locus for civic life in Siena: the Palazzo Comunale. Academic pestles thus coincide in this performative moment with the magnificent phallic tower (La Torre del Mangia) of the Palazzo Comunale that dominates the city's piazza to this day.

The epilogue of the play, however, shows us that the young Intronati do not really hope to occupy the central and dominant public position in Siena, which is, of course, reserved to the powerful adult men who rule the city. Let us then examine, in conclusion, where the epilogue sends the actors after the comedy is over, and whom they invite to follow them.

Not only the church decorated with the potta da Modena but also the two symbolic inns displaying the opposition between folly and wisdom remain on stage as part of the scenery until the end of the play. ${ }^{92}$ From a multitude of Renaissance comedies, we know the commonplace of inviting the audience to celebrate the concluding marriage(s) with the characters in the epilogue. Can we be sure that in this play all the male and female 'figures' involved in the theatrical performance-actors, characters, and audience-are united to celebrate the social wisdom of marriage in lo Specchio, the inn that reflects back to society its own normative representation? Since the space of il Matto is enacted in only one scene of the play-and decidedly not in the final scenewe can affirm this for the characters. The metaleptic discourse of the epilogue

See Andrews, 'Gl'Ingannati as a Text for Performance', p. 34. 


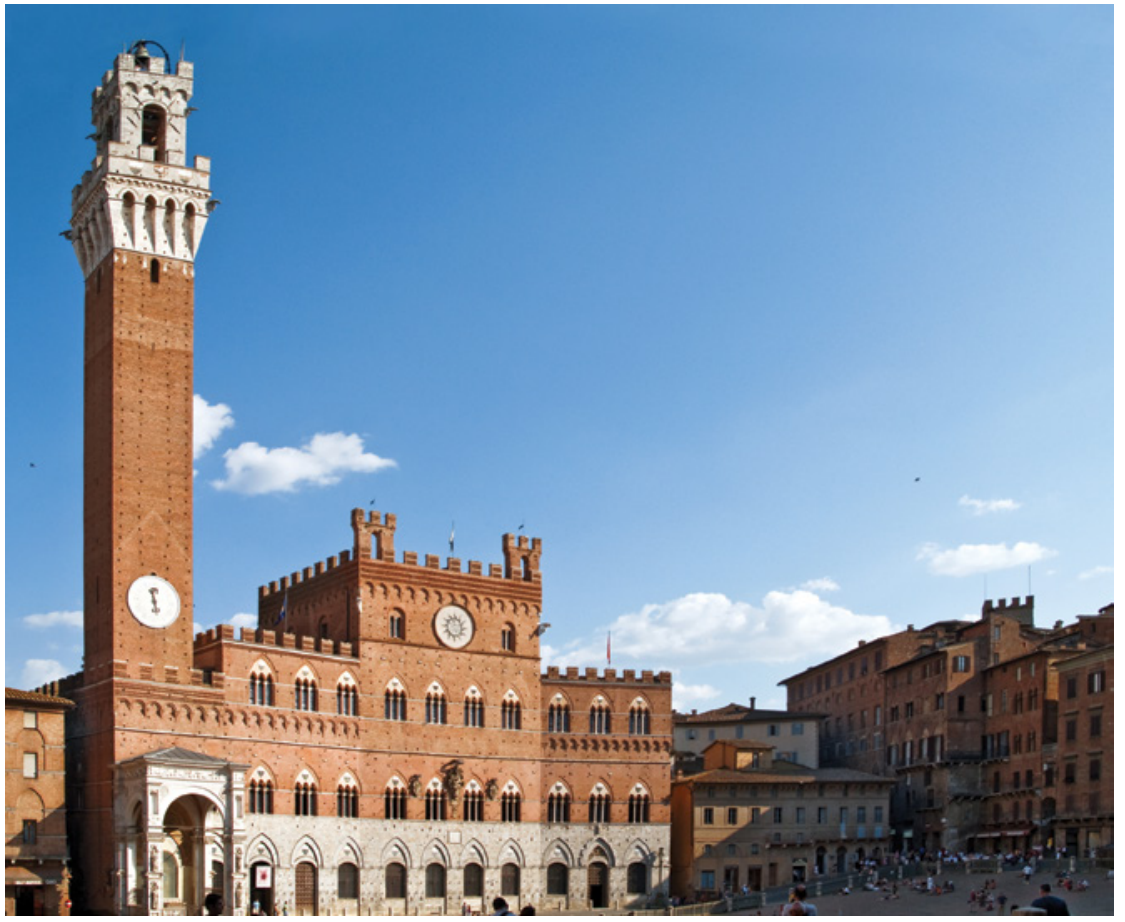

Figure 5 Palazzo Comunale, Siena. Myrabella, CC BY-SA 3.o.

shows us, however, that the fools' play is not finished. Instead, it is transferred from the favola of the comedy to the space of direct interaction between actors and audience.

The epilogue is spoken by the fool Stragualcia, who appears here as the actors' representative. In the name of the Intronati, he announces that the academicians are leaving the Palazzo Comunale and going for dinner at il Matto, the Inn of the Fool, and he invites the spettatori to join them: 'Spectators, [...] if you want to come to dinner with us, I'll be waiting for you at the Joker [il Matto]. And bring along some money, because no one's treating. But if you don't want to come-and it looks to me like that's the case-be happy and enjoy yourselves. And you members of the Intronati, how about some applause?' ('Spettatori, [...]. Se volete venire a cena con esso noi, v'aspetto al Matto. E portate denari, perché non v'è chi espedisca gratis. Ma se non volete venire (che mi par di no), restativi e godete. E voi, Intronati, fate segno d'allegrezza', p. 248).

According to Giannetti's feminist reading of Gl'Ingannati, the Intronati invite the ladies of the audience, associating them with the enterprising Lelia, to 
enjoy 'their liberating ludi at the Matto'. ${ }^{93}$ For purely grammatical reasons, the apostrophe spettatori cannot be applied only to women. It could, theoretically, include men and women, but such a reading would contradict the Intronati's consequent rhetorical practice of gendering the audience and addressing female audience members with the ritualised and emphatic apostrophe nobilissime donne. Besides these grammatical and rhetorical arguments against the association of donne with spettatori, we must also take into consideration that the kind of sociability associated with the image of the inn is incompatible with the noble ladies who formed the female part of the audience. Giannetti, who does not miss this point, insists nevertheless that the invitation to the inn (an invitation that, in my opinion, could only have offended noblewomen) should be understood as a philogynous statement indicative of the Intronati's striving to include women in their circle. I would argue, instead, that the inn is constructed in the play not as an imaginary field of feminine emancipation but as a traditional urban space of masculine sociability. Let us recall that, among the myriad visitors to both inns, the Intronati do not mention even one woman. The epilogue confirms this masculine configuration of the inn, presenting it as an egalitarian space where no one has a privileged position but all contribute to expenses - in other words, a space of male friendship incompatible with the Intronati's courtly attitude towards noblewomen. Departing from this social construction of the inn, il Matto is elaborated, in the epilogue, as a symbolic construction with two different meanings, both of which are evident in the plot via the device of sending to the inn both a deviant adult man and an innocent young boy. These meanings arise from the dialectics of carnivalesque laughter and from the double ritual function of the figure of the fool.

By forming fools' societies, unmarried male youths united under the positive sign of folly that corresponds to the laughter of inclusion and to carnivalesque enjoyment. Il Matto therefore appears in the epilogue first as a utopian space for foolish youth, where the Intronati retire as young men who don't yet belong to the seriousness of the adult world of marriage - a world to which they have brought their characters, thus fulfilling their traditional mission as a youth society that not only enjoys the pleasures of juvenescence but also reveals the right path to its young members. Among the spettatori who are invited to join the actors, we must include adolescents and young unmarried men from the audience who identify themselves with young Fabrizio as he appears at the beginning of the play when he enters the Matto-potential members of 
their fools' company, a company that is here constructed via the carnivalesque laughter of inclusion.

By suggesting that their invitation to il Matto might not be accepted, the Intronati confront their male audience with the negative side of Folly that fools' societies ritually enact in their charivaris (putting fool's caps and other signs of reproach on the heads of deviant adult men) and that appears in the comedy when the sodomite chooses to enter il Matto. In its second symbolic meaning, il Matto is thus modelled as a satirical space of deviance to which the Intronati 'invite' their potential victims: adult male audience members whose virility and morals might be endangered for whatever reason and who become objects of the laughter of exclusion.

We might thus consider the ambiguous invitation to il Matto by the young playwright-actor-fools as a concluding riddle addressed to male audience members in order to test their social vision and to teach them to recognise the important distinction between the licensed foolishness of youth and the condemnable folly of adult members of sixteenth-century Sienese society. 